\title{
Article \\ Curcumin and Its New Derivatives: Correlation between Cytotoxicity against Breast Cancer Cell Lines, Degradation of PTP1B Phosphatase and ROS Generation
}

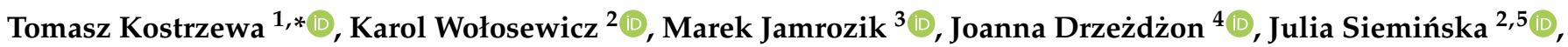 \\ Dagmara Jacewicz ${ }^{4}\left(\mathbb{D}\right.$, Magdalena Górska-Ponikowska ${ }^{1,6,7}$, Marcin Kołaczkowski ${ }^{3}{ }^{\circledR}$, Ryszard Łaźny ${ }^{2}{ }^{\circledR}$ \\ and Alicja Kuban-Jankowska $1, *$ (1)
}

check for

updates

Citation: Kostrzewa, T;

Wołosewicz, K.; Jamrozik, M.;

Drzeżdżon, J.; Siemińska, J.;

Jacewicz, D.; Górska-Ponikowska, M.; Kołaczkowski, M.; Łaźny, R.;

Kuban-Jankowska, A. Curcumin and

Its New Derivatives: Correlation

between Cytotoxicity against Breast

Cancer Cell Lines, Degradation of

PTP1B Phosphatase and ROS

Generation. Int. J. Mol. Sci. 2021, 22,

10368. https://doi.org/10.3390/

ijms221910368

Academic Editor: Chiara Laezza

Received: 26 August 2021

Accepted: 22 September 2021

Published: 26 September 2021

Publisher's Note: MDPI stays neutral with regard to jurisdictional claims in published maps and institutional affiliations.

Copyright: (C) 2021 by the authors Licensee MDPI, Basel, Switzerland. This article is an open access article distributed under the terms and conditions of the Creative Commons Attribution (CC BY) license (https:/ / creativecommons.org/licenses/by/ $4.0 /)$
1 Department of Medical Chemistry, Faculty of Medicine, Medical University of Gdansk, 80-211 Gdansk, Poland; magdalena.gorska-ponikowska@gumed.edu.pl

2 Faculty of Chemistry, University of Bialystok, Ciolkowskiego 1K, 15-245 Bialystok, Poland; k.wolosewicz@uwb.edu.pl (K.W.); julia.sieminska@umb.edu.pl (J.S.); lazny@uwb.edu.pl (R.Ł.)

3 Department of Medicinal Chemistry, Faculty of Pharmacy, Jagiellonian University Medical College, 30-688 Krakow, Poland; marek.jamrozik@doctoral.uj.edu.pl (M.J.); marcin.kolaczkowski@uj.edu.pl (M.K.)

4 Department of Environmental Technology, Faculty of Chemistry, University of Gdansk, Wita Stwosza 63, 80-308 Gdansk, Poland; joanna.drzezdzon@ug.edu.pl (J.D.); dagmara.jacewicz@ug.edu.pl (D.J.)

5 Metabolomics Laboratory, Clinical Research Center, Medical University of Bialystok, 15-276 Bialystok, Poland

6 The Euro-Mediterranean Institute of Science and Technology, 90139 Palermo, Italy

7 Institute of Biomaterials and Biomolecular Systems, Department of Biophysics, University of Stuttgart, 70174 Stuttgart, Germany

* Correspondence: tomasz.kostrzewa@gumed.edu.pl (T.K.); alicja.kuban-jankowska@gumed.edu.pl (A.K.-J.)

Abstract: Breast cancer is the most common cancer of women-it affects more than 2 million women worldwide. PTP1B phosphatase can be one of the possible targets for new drugs in breast cancer therapy. In this paper, we present new curcumin derivatives featuring a 4-piperidone ring as PTP1B inhibitors and ROS inducers. We performed cytotoxicity analysis for twelve curcumin derivatives against breast cancer MCF-7 and MDA-MB-231 cell lines and the human keratinocyte HaCaT cell line. Furthermore, because curcumin is a known antioxidant, we assessed antioxidant effects in its derivatives. For the most potent cytotoxic compounds, we determined intracellular ROS and PTP1B phosphatase levels. Moreover, for curcumin and its derivatives, we performed real-time microscopy to observe the photosensitizing effect. Finally, computational analysis was performed for the curcumin derivatives with an inhibitory effect against PTP1B phosphatase to assess the potential binding mode of new inhibitors within the allosteric site of the enzyme. We observed that two tested compounds are better anticancer agents than curcumin. Moreover, we suggest that blocking the $-\mathrm{OH}$ group in phenolic compounds causes an increase in the cytotoxicity effect, even at a low concentration. Furthermore, due to this modification, a higher level of ROS is induced, which correlates with a lower level of PTP1B.

Keywords: curcumin derivatives; PTP1B phosphatase; breast cancer; ROS generation

\section{Introduction}

The prevalence of various types of cancer leads scientists to look for new active substances that can serve as medicines. Although there are many anti-cancer drugs being revealed, there is still a significant number of limitations that prevent effective therapy, such as multi-drug resistance, unselective targeting of cancer and normal cells, poor outcomes, and recurrence of cancer (relapse of cancer). Among the various groups of potential drug candidates, low molecular weight organic compounds are a major group and many of them are derived from biomolecules of natural origin. One of the prospective substances, due to a wide range of activity in vivo tests and low toxicity, is curcumin [(1,7-bis(4-hydroxy-3methoxyphenyl)-1,6-heptadiene-3,5-dione)] (Figure 1) [1,2]. 


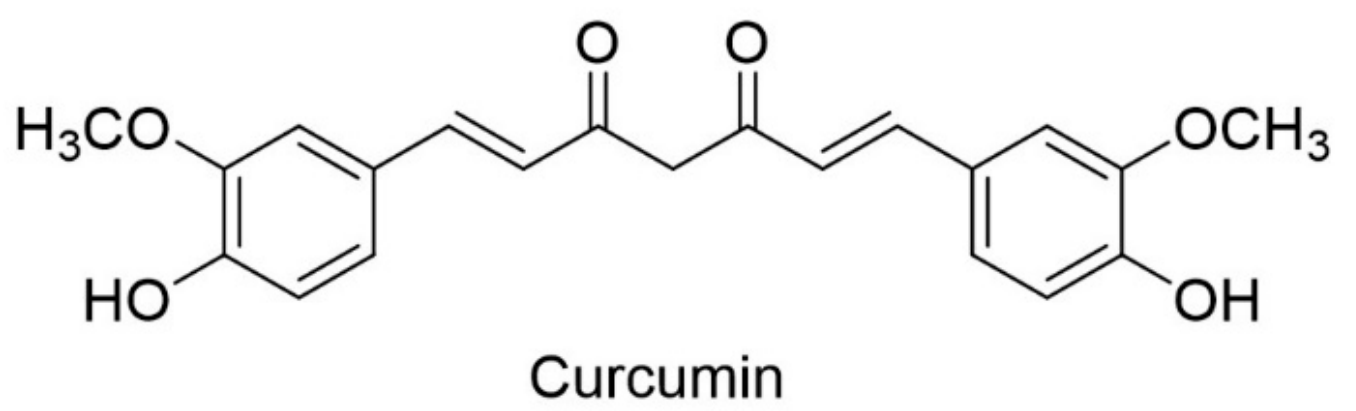

Figure 1. Structure of curcumin (ketone tautomer).

This phenolic compound is a constituent of the natural ingredient of the rhizome of Curcuma longa and is widely used in traditional eastern medicine. As a food additive, it can be safely consumed in huge doses - up to $12 \mathrm{~g}$ in a single dose [3]. Curcumin, in the tests conducted, shows antioxidant [4], anti-inflammation [5], anti-fungal [6], anti-cancer [7], and many other biological activities [8,9]. Although curcumin has many promising properties, it has poor bioavailability and a weak pharmacokinetic profile. The reasons for this are poor solubility in aqueous gastrointestinal fluids, week absorption in the gastrointestinal tract, and instability at physiological $\mathrm{pH}$-at a $\mathrm{pH}$ of 7.2-8.0, the half-life of curcumin is only 1 to $9 \mathrm{~min}$. The presence of proteins increases stability, but after $1 \mathrm{~h}$ about $20 \%$ of curcumin is still degraded in human blood [10]. The main obstacles in the application of curcumin as an active pharmaceutical ingredient are its fast metabolism and elimination from the human body, poor water solubility, and chemical instability [11].

Many biological activities and negligible negative impacts on the human body (turmeric, the constituent of which is curcumin, has been used in Indian cuisine for centuries) [12] prompts scientists to look for a way to improve the bioavailability of curcumin [13] or to develop its derivatives with increased bioavailability [8]. One of the strategies to improve the bioavailability of curcumin analogues is the incorporation of a nitrogen atom in the molecule. Such a molecule will have a secondary interaction site-a hydrogen bond acceptor. This modification may increase the antiproliferative properties of the tested compounds [14]. The effect of incorporating a nitrogen atom in the structure of curcumin analogues with a 4-piperidone cyclic core was studied [14-16], and some of the tested compounds demonstrated very good antiproliferative activities [17]. For this reason, we decided to incorporate the heterocyclic structure of 4-piperidone into a curcumin molecule. Unfortunately, the majority of studied analogues with a 4-piperidone ring were monocarbonyl analogues of curcumin (MACs) $[8,17,18]$. The lack of a 1,3-diketone moiety characteristic for curcumin in those compounds may significantly affect their biological activity. It was reported that the enol form of 1,3-diketone is responsible for some curcumin activity. The curcumin analogues that cannot take the enol form (have a fluorine atom instead of hydrogen in the methylene position between carbonyl groups) showed significantly lower activity in the anti-androgen activity in LNCaP and PC-3 prostate cancer cells tests compared to the enolizing (non-fluorinated) compounds [19]. Unfortunately, curcumin analogues with a 4-piperidone structure fused with the 1,3-diketone moiety are, to the best of our knowledge, unknown. For these reasons, we decided to investigate 1,3-diketone curcumin analogues with a 4-piperidone ring in our research.

Protein tyrosine phosphatases (PTPs) regulate the tyrosine phosphorylation process, which is responsible for the control of cell adhesion and migration. The human genome contains more than one hundred different genes of protein tyrosine phosphatases (just as protein tyrosine kinase genes) coding for approximately five types of phosphatases. A large number of existing various protein tyrosine phosphatases result from the fact that PTP genes are able to produce different products through a process called alternative splicing, which in turn may undergo post-translational modifications [20]. Phosphorylation and dephosphorylation of the tyrosine residues of proteins is an evolutionarily preserved mechanism of signal transduction in eukaryotic cells that is of fundamental importance 
in the control of cell physiology, including proliferation, differentiation, migration, and tumorigenesis. Reversible tyrosine phosphorylation of proteins is regulated by a balance between the antagonistic action of protein tyrosine phosphatases and tyrosine kinases [21]. Their balanced and opposing action is crucial for the maintenance of homeostasis, and any interference can contribute to the development of the diseases and the process of carcinogenesis. Abnormal tyrosine phosphorylation may lead to cancer characterized by abnormal growth and metastatic potential. There is evidence that some of the PTPs can stimulate the process of tumorigenesis because many protein tyrosine phosphatases in human organisms are responsibilities for regulating other proteins and their malfunction may cause activity of growth factors and may promote tumor formation [22,23]. The role of protein tyrosine phosphatases in the formation and development of tumors was presented during the implementation of a number of scientific research studies. The participation of PTPs in the development of glioma, colorectal cancer, lung cancer, breast cancer, and multiple myeloma has been proven [24].

Regulatory mechanisms of PTP1B play a significant role in the proper functioning of the immune system, and altered expression of the gene encoding this enzyme may be one of the causes of some types of cancer, autoimmune diseases, metabolic diseases, or viral infections. Due to the above, modulation of PTP1B phosphatase activity with inhibitors may play an important role in modern pharmacotherapy. Therefore, we also tested the new curcumin derivatives for inhibitory activity against PTP1B phosphatase.

\section{Results}

\subsection{Synthesis}

Synthesis of most of the investigated compounds (Figure 2) was conducted according to a procedure reported before [25]. Only compound 9, which was synthesized by the direct reaction of 4-piperidone and vanillin under acidic conditions [26], and compound 1 were commercially available.

The activity of both products (compound 2 and compound 10) was examined in our research. The configuration of the 2-benzylidenepiperidones obtained has been confirmed as $E$, based on chemical shifts in the ${ }^{1} \mathrm{H}$-NMR spectra (the olefinic $\mathrm{H}$ singlet was observed at $7.50 \mathrm{ppm} 2,7.74 \mathrm{ppm} 10$, and 7.53 9). The typical chemical shifts in the ${ }^{1} \mathrm{H}-\mathrm{NMR}$ spectra for the $Z$ isomers are in the range of 6.0-6.5 ppm [27].

In the next step, lithium enolates generated in the reaction of the ketones with LDA were acylated with acyl cyanides affording compounds 4, 6, 8, and 12 (from $\alpha$ benzylidenepiperidones) or compound 3 (from 4-piperydone, Scheme 1). Deprotection of the hydroxyl group was affected under alkaline conditions ( $10 \%$ ammonia solution in water) affording products 5 and $\mathbf{7}$ in moderate yields (62\% and $48 \%$ ). Only compound $\mathbf{1 1}$ was obtained with a lower yield (35\%) due to difficulty in purification of the productchromatography repeated several times resulted in an impure product, which had to be purified by recrystallization with dichloromethane (DCM). The constant $J$ values and the chemical shift of the double bonds of the crotonyl moieties in the ${ }^{1} \mathrm{H}-\mathrm{NMR}$ spectra were similar to the acyl cyanides, which confirmed that the product has an unchanged $E$ configuration. The chemical shift above $16 \mathrm{ppm}$ of the hydrogen in the methylene position between carbonyl groups in the ${ }^{1} \mathrm{H}-\mathrm{NMR}$ spectra proved that the 1,3-dicarbonyl moiety was predominantly in the enol form. That fact has been confirmed in the literature by $\mathrm{X}$-ray of a similar compound [25]. However, in an analogy to the curcumin molecule, which is usually drawn in the keto form, we decided to show the curcumin analogues with a 1,3-diketone moiety in the ketone form in this paper. 
<smiles>COc1cc(C=C2CN(C)CCC2=O)ccc1O</smiles><smiles>COc1cc(/C=C/C(=O)C2CN(C)C/C(=C\c3ccccc3)C2=O)ccc1O</smiles><smiles>COC(=O)Oc1ccc(C=C2CN(C)CCC2=O)cc1OC</smiles><smiles>COC(=O)Oc1ccc(/C=C/C(=O)C2CN(C)C/C(=C\c3ccccc3)C2=O)cc1OC</smiles><smiles>COC(=O)Oc1ccc(/C=C/C(=O)C2CN(C)CCC2=O)cc1OC</smiles><smiles>COc1cc(/C=C2\CN(C)C/C(=C\c3ccc(O)c(OC)c3)C2=O)ccc1O</smiles><smiles>CN1C/C(=C\c2ccccc2)C(=O)C(C(=O)/C=C/c2ccccc2)C1</smiles><smiles>COC(=O)Oc1ccc(C=C2CN(C)CC(=Cc3ccc(OC(=O)OC)c(OC)c3)C2=O)cc1OC</smiles><smiles>COc1cc(/C=C2\CN(C)CC(C(=O)/C=C/c3ccccc3)C2=O)ccc1O</smiles><smiles>COc1cc(C=C2CN(C)CC(C(=O)/C=C/c3ccc(O)c(OC)c3)C2=O)ccc1O</smiles><smiles>COC(=O)Oc1ccc(/C=C2\CN(C)CC(C(=O)/C=C/c3ccccc3)C2=O)cc1OC</smiles><smiles>COC(=O)Oc1ccc(/C=C/C(=O)C2CN(C)C/C(=C\c3ccc(OC(=O)OC)c(OC)c3)C2=O)cc1OC</smiles>

Figure 2. Structures of the obtained curcumin analogues. The first step of the synthesis was the aldol reaction of 4-piperidone and selected aldehydes (benzaldehyde or 3-methoxy-4-methoxycarbonyloxybenzaldehyde) promoted by lithium diisopropylamide (LDA) in anhydrous tetrahydrofuran (THF). The obtained aldols were dehydrated (elimination of water) in acidic conditions to obtain monosubstituated benzylidene piperidones. We chose a complicated procedure using LDA in anhydrous conditions to avoid obtaining only the thermodynamically stable product of attachment of two aldehyde molecules, the formation of which was observed under both acidic and basic conditions [16,26]. In the synthesis of compound $\mathbf{2}$, the hydroxyl group of aldol was acetylated (catalyzed by DMAP: 4-(dimethylamino)pyridine) before acid-catalyzed elimination. This transformation allows one to perform the elimination reaction under milder conditions (without heating) and increase the yield of obtained product [25]. Unfortunately, despite those preventive measures, in addition to the desired product 2 (29\% yield), 2,4-disubstituated piperidone 10 (14\% yield) was obtained (Scheme 2). 
<smiles>[R]c1ccc(C=C2CN(C)CCC2=O)cc1[R]</smiles>

2: $\mathrm{R}^{1}=\mathrm{OCH}_{3}, \mathrm{R}^{2}=\mathrm{OC}(\mathrm{O}) \mathrm{OCH}_{3}$ 3-Benzylidene-1-methylpiperidin-4-one: $R^{1}=H, R^{2}=H$
1) $\mathrm{LDA}$, THF

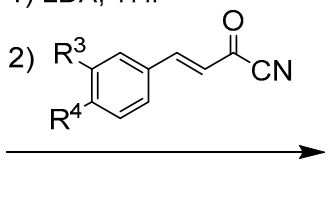<smiles>[R]c1ccc(/C=C/C(=O)C2CN(C)C/C(=C\c3ccc([R])c([R])c3)C2=O)cc1[R]</smiles>

4: $\mathrm{R}^{1}=\mathrm{H}, \mathrm{R}^{2}=\mathrm{H}, \mathrm{R}^{3}=\mathrm{H}, \mathrm{R}^{4}=\mathrm{H}$

6: $R^{1}=\mathrm{OCH}_{3}, \mathrm{R}^{2}=\mathrm{OC}(\mathrm{O}) \mathrm{OCH}_{3}, \mathrm{R}^{3}=\mathrm{H}, \mathrm{R}^{4}=\mathrm{H}$

8: $R^{1}=H, R^{2}=H, R^{3}=O_{3} H_{3}, R^{4}=\mathrm{OC}(\mathrm{O}) \mathrm{OCH}_{3}$

12: $R^{1}=\mathrm{OCH}_{3}, \mathrm{R}^{2}=\mathrm{OC}(\mathrm{O}) \mathrm{OCH}_{3}$, $\mathrm{R}^{3}=\mathrm{OCH}_{3}, \mathrm{R}^{4}=\mathrm{OC}(\mathrm{O}) \mathrm{OCH}_{3}$<smiles>[R]c1ccc(/C=C/C(=O)C2CN(C)C/C(=C\c3ccc([R])c([R])c3)C2=O)cc1[R]</smiles>

5: $\mathrm{R}^{1}=\mathrm{OCH}_{3}, \mathrm{R}^{2}=\mathrm{OH}, \mathrm{R}^{3}=\mathrm{H}, \mathrm{R}^{4}=\mathrm{H}$

7: $R^{1}=\mathrm{H}, \mathrm{R}^{2}=\mathrm{H}, \mathrm{R}^{3}=\mathrm{OCH}_{3}, \mathrm{R}^{4}=\mathrm{OH}$

11: $R^{1}=\mathrm{OCH}_{3}, \mathrm{R}^{2}=\mathrm{OH}, \mathrm{R}^{3}=\mathrm{OCH}_{3}, \mathrm{R}^{4}=\mathrm{OH}$

Scheme 1. Synthesis of dicarbonyl curcumin analogues.<smiles>COC(=O)Oc1ccc(C=C2CN(C)CCC2=O)cc1OC</smiles><smiles>COC(=O)Oc1ccc(/C=C2\CN(C)C/C(=C\c3ccc(OC(=O)OC)c(OC)c3)C2=O)cc1OC</smiles>

$\uparrow$

1) LDA, THF

2) $\mathrm{CH}_{3} \mathrm{O} \approx \mathrm{CHO}$ $\mathrm{O}=\mathrm{OCH}_{3}$

3) Acetic anhydride, DMAP

4) Acetic acid
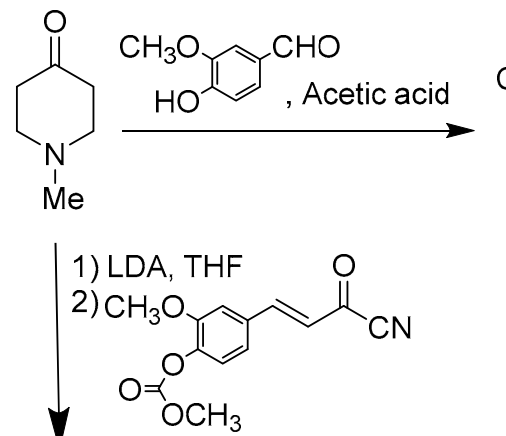<smiles>COC(=O)Oc1ccc(/C=C/C(=O)C2CN(C)CCC2=O)cc1OC</smiles>

Scheme 2. Synthesis of monocarbonyl curcumin analogues and compound 3. 


\subsection{Low Concentration of Synthesized Derivatives of Curcumin Showed Antioxidant Effect}

All tested compounds are characterized by high reactivity towards the superoxide radical anion. Curcumin and its derivatives react with the superoxide anion to form a product with maximum absorption at $560 \mathrm{~nm}$. On the other hand, for the purpose of the studies described in this report, such low concentrations of compounds were selected so that the possibility of product formation did not interfere with the absorbance measurements. After the antioxidants reacted with the superoxide anion, part of the superoxide anion radicals in the tested sample remained and reacted with nitro blue tetrazolium (NBT) to form formazan. The values of percent superoxide anion scavenging by curcumin and its derivatives are presented in Table 1.

Table 1. The values of percent superoxide anion scavenging by curcumin and its derivatives.

\begin{tabular}{ccc}
\hline Antioxidant & Concentration $[\mu \mathrm{M}]$ & Scavenging $[\%]$ \\
\hline Curcumin & $\mathbf{0 . 0 5}$ & $\mathbf{7}$ \\
Compound 1 & 1000 & 5 \\
Compound 2 & 1000 & 11 \\
Compound 3 & 0.50 & 1 \\
Compound 4 & 0.05 & 3 \\
Compound 5 & 5.00 & 5 \\
Compound 6 & 0.05 & 6 \\
Compound 7 & 6.25 & 3 \\
Compound 8 & $\mathbf{0 . 0 5}$ & $\mathbf{1 8}$ \\
Compound 9 & $\mathbf{0 . 0 8}$ & $\mathbf{1 4}$ \\
Compound 10 & 0.50 & 3 \\
Compound 11 & 0.50 & $*$ \\
Compound 12 & $\mathbf{0 . 0 5}$ & $\mathbf{9}$ \\
L-ascorbic acid [28] & 0.05 & 9.45 \\
\hline
\end{tabular}

* For compound 11, it was not possible to select the concentration in which the formation of the product with the radical anion would not interfere with the measurement of absorbance at $560 \mathrm{~nm}$.

The results show that compound $\mathbf{1 2}$ and compound $\mathbf{8}$ are better antioxidants than curcumin, which is known as a good antioxidant. The chemical compound $\mathbf{9}$ is also worth attention because at a low concentration showed relatively high antioxidant activity.

\subsection{Curcumin and Its Derivatives Show Cytotoxicity Effect against Breast Cancer Cell Line}

We assessed the cytotoxicity and calculated $\mathrm{IC}_{50}$ values for curcumin and its new derivatives against breast cancer MCF-7 and MDA-MB-231 cell lines and the human keratinocyte HaCaT cell line (as a non-cancerous control). Cells were treated with serial concentrations (7.81 to $100 \mu \mathrm{M}$ ) of each compound, and then the cells were incubated for $24 \mathrm{~h}$. Based on the obtained results, we determined the $\mathrm{IC}_{50}$ using a nonlinear log (inh) vs. normalized response-variable slope (Table 2) for compounds, which showed 50\% cytotoxicity below the $100 \mu \mathrm{M}$ concentration level.

We observed that compounds 5 and $\mathbf{6}$ showed a better cytotoxic effect against both types of breast cancer cell lines in comparison to all tested compounds. Against the MCF-7 cell line, the cytotoxic agents better than curcumin are compounds $3, \mathbf{1 0}$, and 11. It is worth noting that compounds $\mathbf{5}$ and $\mathbf{6}$ showed a higher selectivity index than other compounds, both against MCF-7 and MDA-MB-231 cell lines. Based on the ratio of the $\mathrm{IC}_{50}$ values determined for non-tumor-transformed cells to breast cancer cells, it can be observed that compound 5 showed cytotoxicity 1.63 times higher against MCF-7 cells compared to $\mathrm{HaCaT}$ cells and 1.29 times higher against MDA-MB-231 cells compared to HaCaT cells. On the other hand, its analogue (compound 6) showed similar cytotoxicity in the concentration range of 12.5-100 $\mu \mathrm{M}$ for MCF-7 and HaCat cells; however, it showed 2.61 times higher cytotoxicity for MDA-MB-231 cells than for HaCat cells. Moreover, it is worth noting that both compounds 5 and $\mathbf{6}$ have substituents on the aromatic ring proximal to the piperazine ring. The difference between these compounds was the protection of the $-\mathrm{OH}$ group at position 4 in the aromatic ring (compound 6) compared to the free -OH group 
(compound 5). Protection of the -OH group increased cytotoxicity in the low concentration range of 7.81-12.5 against the MCF-7 cell line (reduce viability to $78-62 \%$ ) and in the concentration range of 3.125-6.25 $\mu \mathrm{M}$ against MDA-MB-231 (reduced viability to 79-55\%) cells (Figure 3).

Table 2. $\mathrm{IC}_{50}$ values against MCF-7, MDA-MB-231, and HaCaT cell lines for curcumin and its new derivatives.

\begin{tabular}{|c|c|c|c|c|c|}
\hline & \multicolumn{3}{|c|}{$\mathrm{IC}_{5 \mathrm{O}}[\mu \mathrm{M}] \pm \mathrm{SD}$} & \multicolumn{2}{|c|}{ Selectivity Index (SI) } \\
\hline & MCF-7 & MDA-MB-231 & HaCaT & HaCat/MCF-7 & HaCaT/MDA-MB-231 \\
\hline Curcumin & $37.36 \pm 1.88$ & $57.07 \pm 6.23$ & $19.44 \pm 2.60$ & 0.52 & 0.34 \\
\hline Compound 1 & $79.38 \pm 1.92$ & $>100$ & $60.18 \pm 5.82$ & 0.75 & $<0.60$ \\
\hline Compound 2 & $>100$ & $60.76 \pm 5.04$ & $54.15 \pm 3.67$ & $<0.54$ & 0.89 \\
\hline Compound 3 & $30.99 \pm 6.16$ & $84.23 \pm 7.70$ & $41.02 \pm 1.43$ & 1.32 & 0.49 \\
\hline Compound 4 & $64.38 \pm 11.79$ & $>100$ & $15.31 \pm 1.52$ & 0.23 & $<0.15$ \\
\hline Compound 5 & $25.30 \pm 2.54$ & $31.86 \pm 1.07$ & $41.24 \pm 3.22$ & 1.63 & 1.29 \\
\hline Compound 6 & $30.51 \pm 4.11$ & $11.80 \pm 1.43$ & $30.84 \pm 7.63$ & 1.01 & 2.61 \\
\hline Compound 7 & $42.76 \pm 2.18$ & $49.13 \pm 6.62$ & $16.78 \pm 1.51$ & 0.39 & 0.34 \\
\hline Compound 8 & $39.59 \pm 2.18$ & $37.80 \pm 2.52$ & $21.94 \pm 3.61$ & 0.55 & 0.58 \\
\hline Compound 9 & $>100$ & $>100$ & $10.50 \pm 1.44$ & $<0.11$ & $<0.11$ \\
\hline Compound 10 & $28.27 \pm 1.56$ & $>100$ & $8.38 \pm 3.80$ & 0.30 & $<0.08$ \\
\hline Compound 11 & $32.44 \pm 3.44$ & $92.34 \pm 2.98$ & $52.79 \pm 6.86$ & 1.63 & 0.57 \\
\hline Compound 12 & $>100$ & $71.96 \pm 1.82$ & $18.13 \pm 3.46$ & $<0.18$ & 0.25 \\
\hline Doxorubicin & $0.41 \pm 0.75^{\mathrm{a}}$ & $0.60 \pm 0.36^{\mathrm{a}}$ & $2.72^{b}$ & $6.63^{d}$ & $4.53^{\mathrm{d}}$ \\
\hline Tamoxifen & $24.76 \pm 0.80^{\mathrm{a}}$ & $25.84 \pm 1.60^{\mathrm{a}}$ & $22.00 \pm 1.02^{c}$ & $0.89^{\mathrm{d}}$ & $0.85^{\mathrm{d}}$ \\
\hline
\end{tabular}

${ }^{\mathrm{a}}[29] ;{ }^{\mathrm{b}}[30] ;{ }^{\mathrm{c}}[31] ;{ }^{\mathrm{d}}$ SI calculated based on literature data.

(a)

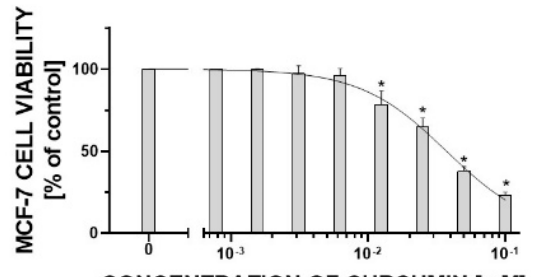

CONCENTRATION OF CURCUMIN [mM]

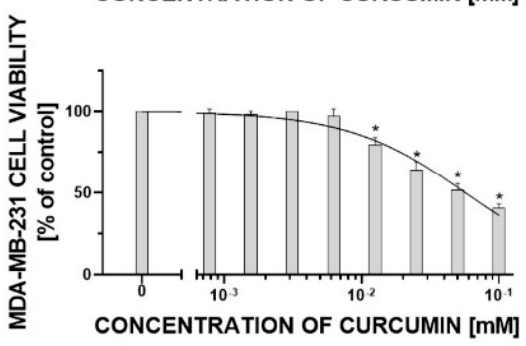

(c)

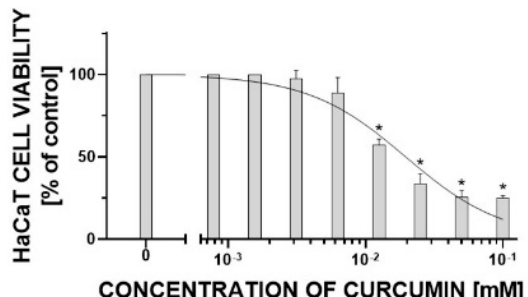

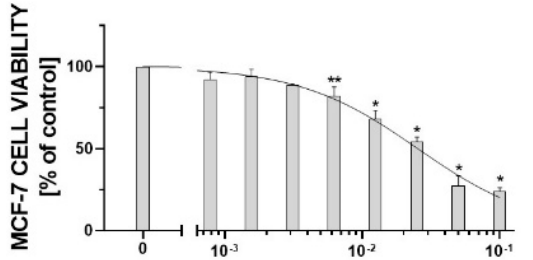
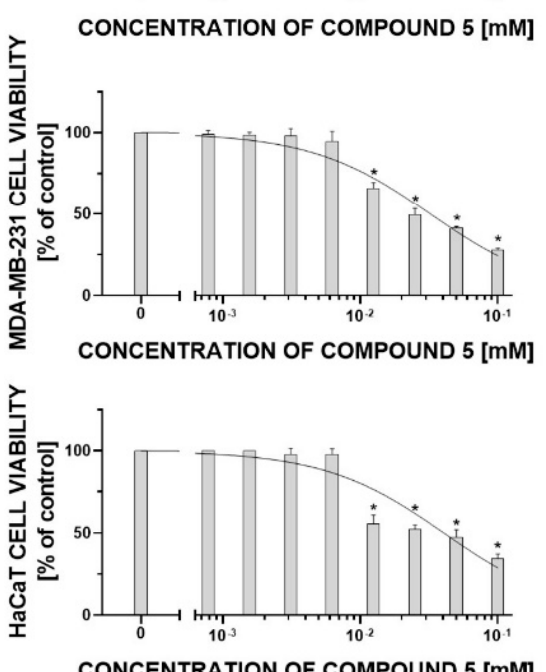

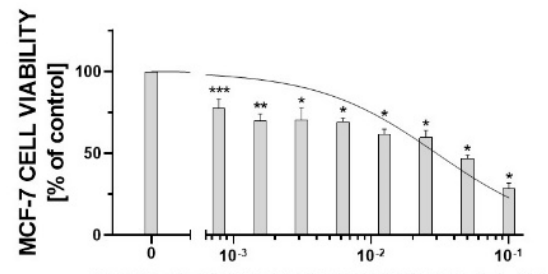

CONCENTRATION OF COMPOUND 6 [mM]

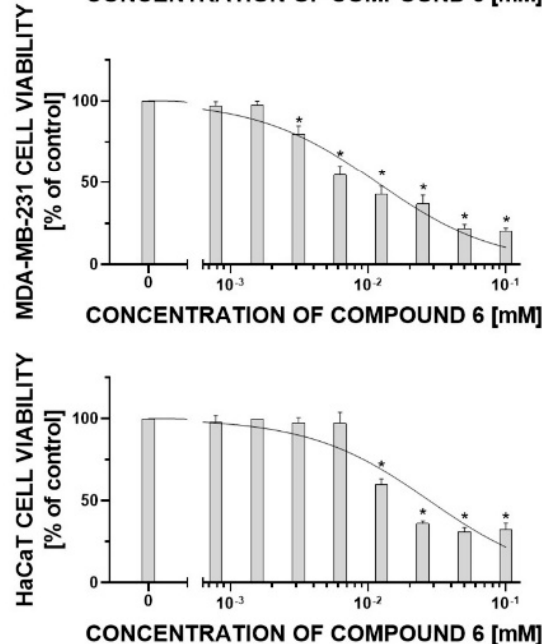

Figure 3. The cellular viability of the (a) MCF-7 cell line, (b) MDA-MB-231 cell line, and (c) HaCat cell line, after $24 \mathrm{~h}$ incubation with different concentrations of curcumin, compound 5 , and compound 6 . The cellular viability was measured by MTT Cell Viability assay. The results were presented as a percentage of control (mean $\pm \mathrm{SD}, n=3,{ }^{*} p<0.0001$; ${ }^{* *} p<0.01$; $* * * p<0.1)$. 


\subsection{Generation of Intracellular ROS Level Corresponds to Degradation of PTP1B}

Based on the cytotoxicity results obtained, for analysis of intracellular reactive oxygen species (ROS) generation in MCF-7, MDA-MB-231, and HaCat cell lines, we chose curcumin and its two derivatives-compound 5 and compound 6 . We observed that curcumin, compound 5, and compound 6 , in a concentration of $25 \mu \mathrm{M}$, triggers the generation of intracellular ROS levels in the breast cancer cell line, whereas they did not generate ROS in a non-tumor-transformed $\mathrm{HaCaT}$ cell line. The strongest ROS generation was induced by compound 6 in a concentration of $25 \mu \mathrm{M}$, both in MCF-7 (205.49 $\pm 27.65 \%)$ and MDA-MB$231(707.29 \pm 34.81 \%)$ cell lines. To correlate the effect of intracellular ROS generation with the degradation of PTP1B phosphatase, we performed Western Blot analysis for curcumin, compound 5 , and compound $\mathbf{6}$ against breast cancer cell lines. As we noted, compound $\mathbf{6}$ was responsible for the strongest degradation of PTP1B phosphatase in MDA-MB-231 cell lines, while in the MCF-7 cell line, compound 5 was slightly stronger. On the other hand, in two tested cell lines, curcumin had the lowest effect on PTP1B levels (Figure 4).

(a)
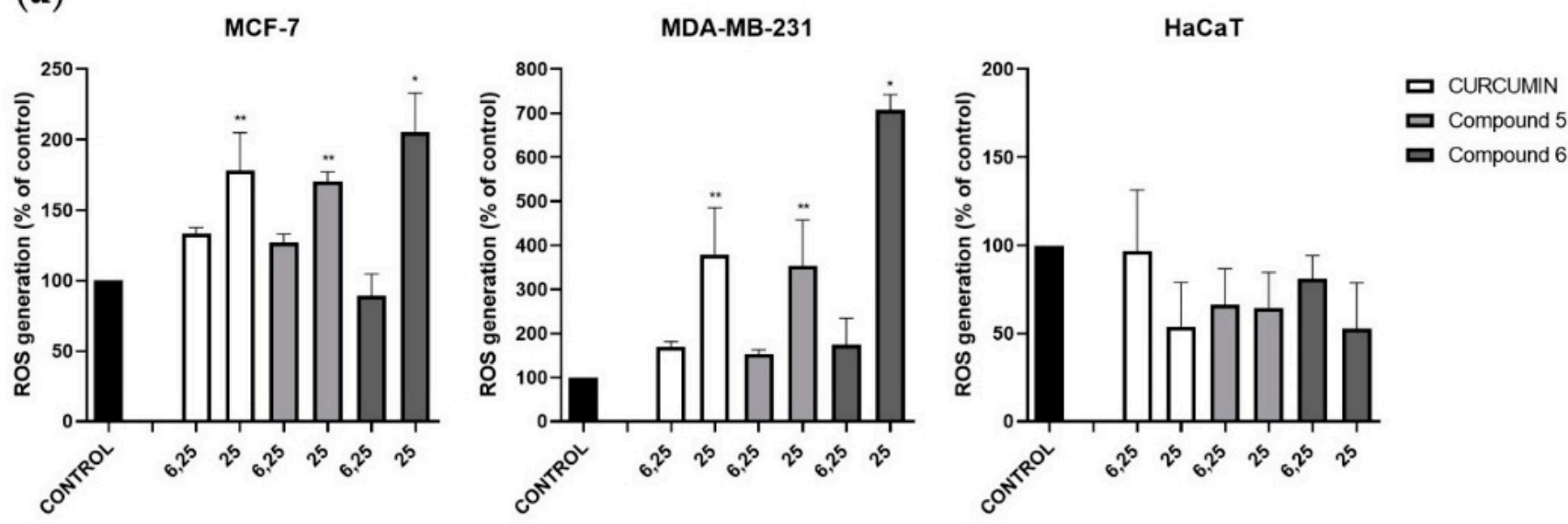

(b) 1 $\begin{array}{lll}0.92 & 0.25 & 0.27\end{array}$

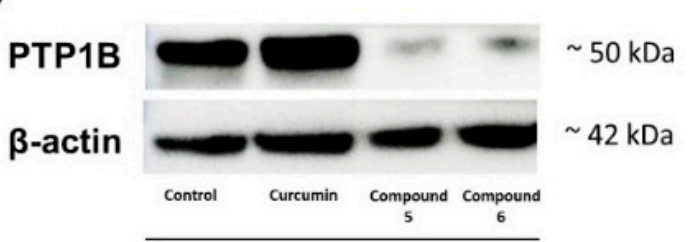

MCF-7

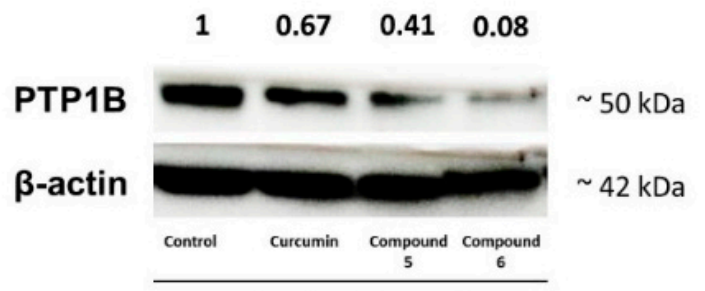

MDA-MB-231

Figure 4. (a) The levels of ROS induced by curcumin, compound 5, and compound 6 in concentrations of 6.25 and $25 \mu \mathrm{M}$ in MCF-7, MDA-MB-231, and HaCaT cell lines after $24 \mathrm{~h}$ of incubation. The results were presented as a percentage of control (mean $\pm \mathrm{SD}, n=3,{ }^{*} p<0.0001 ;{ }^{* *} p<0.01$ ); (b) Western blot of PTP1B expression in cancer cells.

\subsection{Curcumin and Compound 5 Show a Photosensitizing Effect}

The absorption spectrum range for curcumin is between 300 and $500 \mathrm{~nm}$ with a maximum absorption at $435 \mathrm{~nm}$. Many scientific articles indicate that curcumin can be used as a photosensitizer in photodynamic therapy, both against cancer and bacterial cells [32-34]. In our study, we observed the viability of MDA-MB-231 cells treated with curcumin and compound 5 in concentrations of $25 \mu \mathrm{M}$ using a real-time fluorescence microscope. Snapshots were taken every $5 \mathrm{~min}$ for $24 \mathrm{~h}$, using brightfield, green, and red channels in parallel, or brightfield and red channels in parallel. As we noticed, with simultaneous irradiation with the green and red channels (Figure 5b,d), the cytotoxicity of both compounds was higher than when only the red channel was used (Figure 5c,e). We also found that compound $\mathbf{5}$ showed higher cytotoxicity after irradiation with green light than curcumin. 
(a)

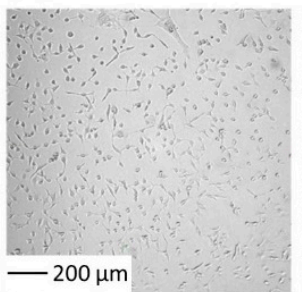

(b)

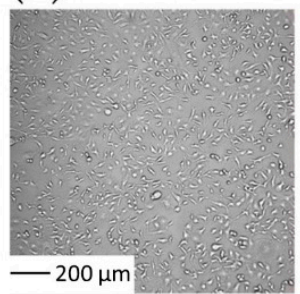

(c)

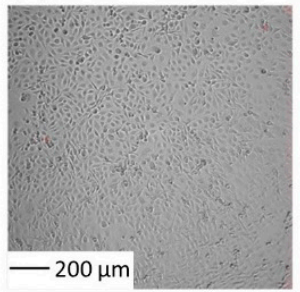

$\mathrm{Oh}$

(d)

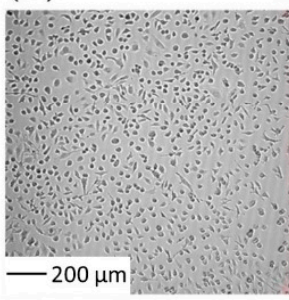

$\mathrm{Oh}$

(e)

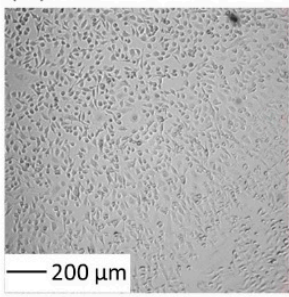

$\mathrm{Oh}$

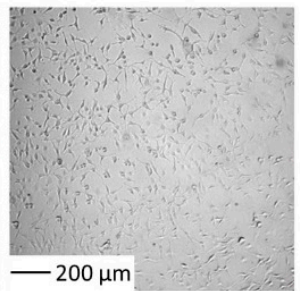

$8 \mathrm{~h}$

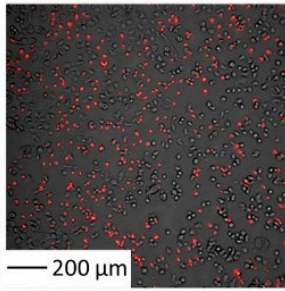

$2 \mathrm{~h}$

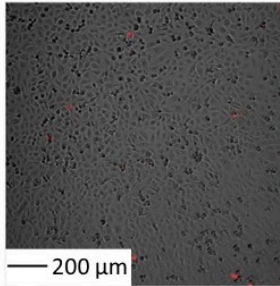

$8 \mathrm{~h}$

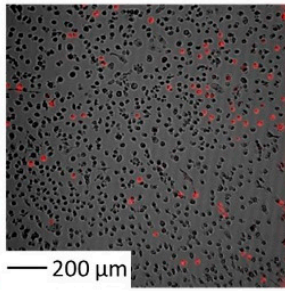

$3 \mathrm{~h}$

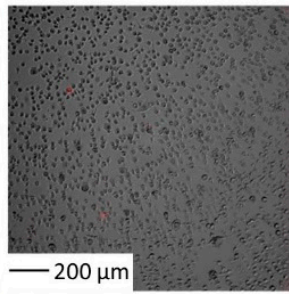

$8 \mathrm{~h}$

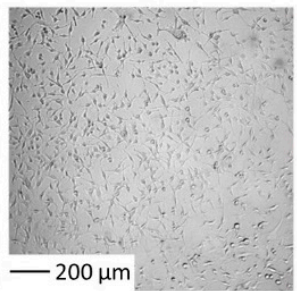

$16 \mathrm{~h}$

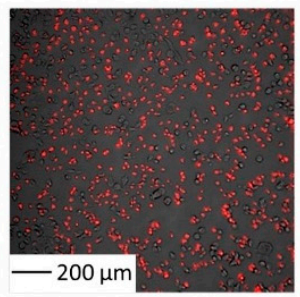

$3 \mathrm{~h}$

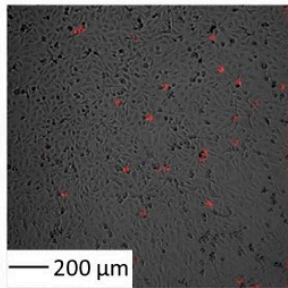

$16 \mathrm{~h}$

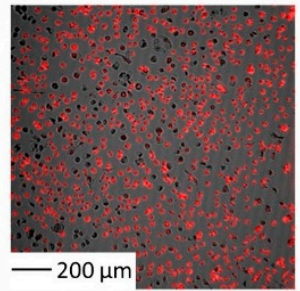

$6 \mathrm{~h}$

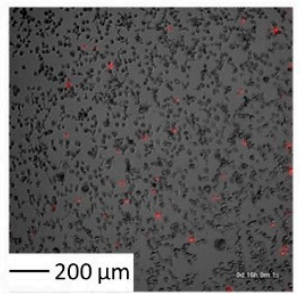

$16 \mathrm{~h}$

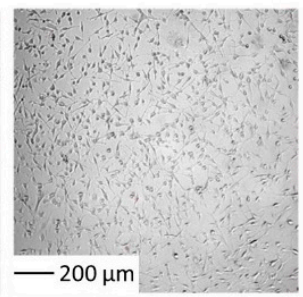

$24 \mathrm{~h}$

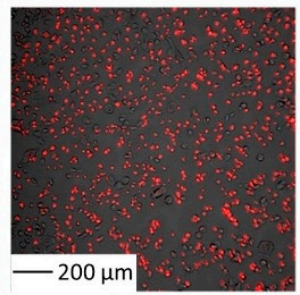

$4 \mathrm{~h}$

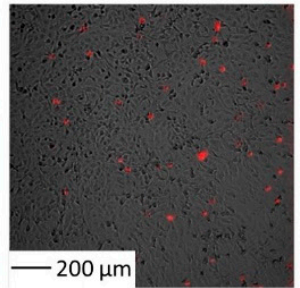

$24 \mathrm{~h}$

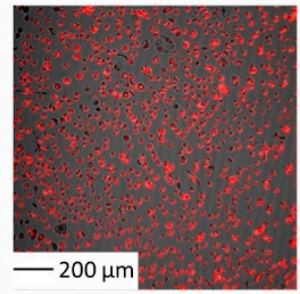

$9 \mathrm{~h}$

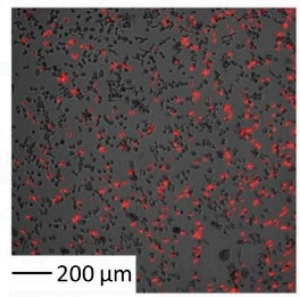

$24 \mathrm{~h}$

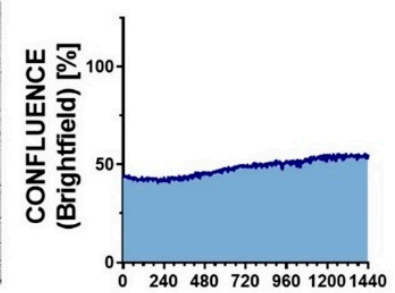

TIME [min]

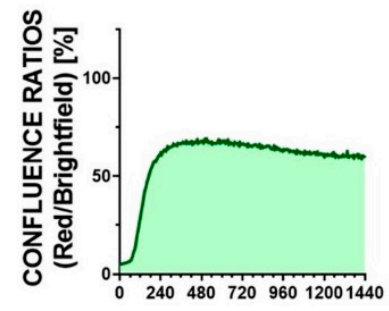

TIME [min]
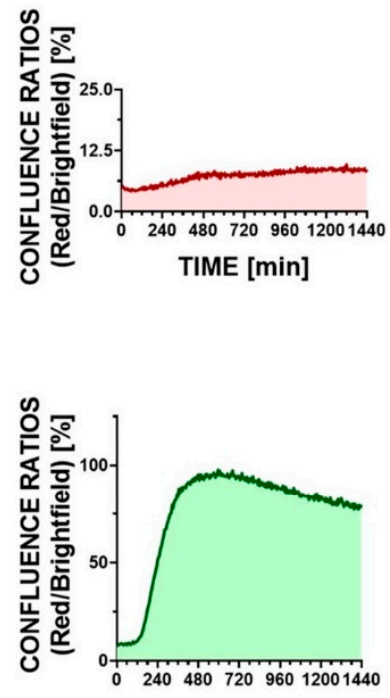

TIME [min]

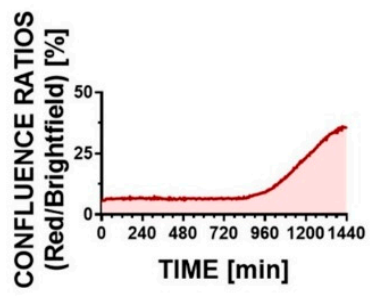

Figure 5. Real-time fluorescence microscopy. Snapshots are presented with the red channel enabled to visualize late apoptotic/necrotic cells. (a) Control cells snapshots—cells were treated with propidium iodide (PI) and registered with brightfield, green, and red channels enabled. The graph shows the confluence of cells. (b) MDA-MB-231 cells treated with PI and $25 \mu \mathrm{M}$ curcumin and registered with brightfield, green, and red channels at the same time. The graph shows confluence ratios for red/brightfield channels; (c) MDA-MB-231 treated with PI and $25 \mu \mathrm{M}$ curcumin and registered with the brightfield and red channels enabled. The graph shows confluence ratios for red/brightfield channels; (d) MDA-MB-231 cells treated with PI and $25 \mu \mathrm{M}$ compound 5 and registered brightfield, green, and red channels enabled at the same time. The graph shows confluence ratios for red/brightfield channels. (e) MDA-MB-231 treated with PI and $25 \mu \mathrm{M}$ compound 5 and registered with the brightfield and red channels enabled. The graph shows confluence ratios for red/brightfield. 


\subsection{Curcumin and Compound 6 Shows Inhibitory Effect against Protein Tyrosine Phosphatase PTP1B}

Due to the previously determined inhibition of PTP1B by curcumin [35], for the obtained derivatives, we conducted a study of the inhibitory potential against protein tyrosine phosphatase PTP1B. Except compound 6, all the derivatives obtained at a concentration of $100 \mu \mathrm{M}$ showed no inhibitory potential towards PTP1B. Compound 6 reduced PTP1B ability to dephosphorylate the substrate by $36 \%$, while curcumin showed a $51 \%$ inhibitory effect (Figure 6). Therefore, we performed a molecular docking simulation for compound 6 on the PTP1B crystal.

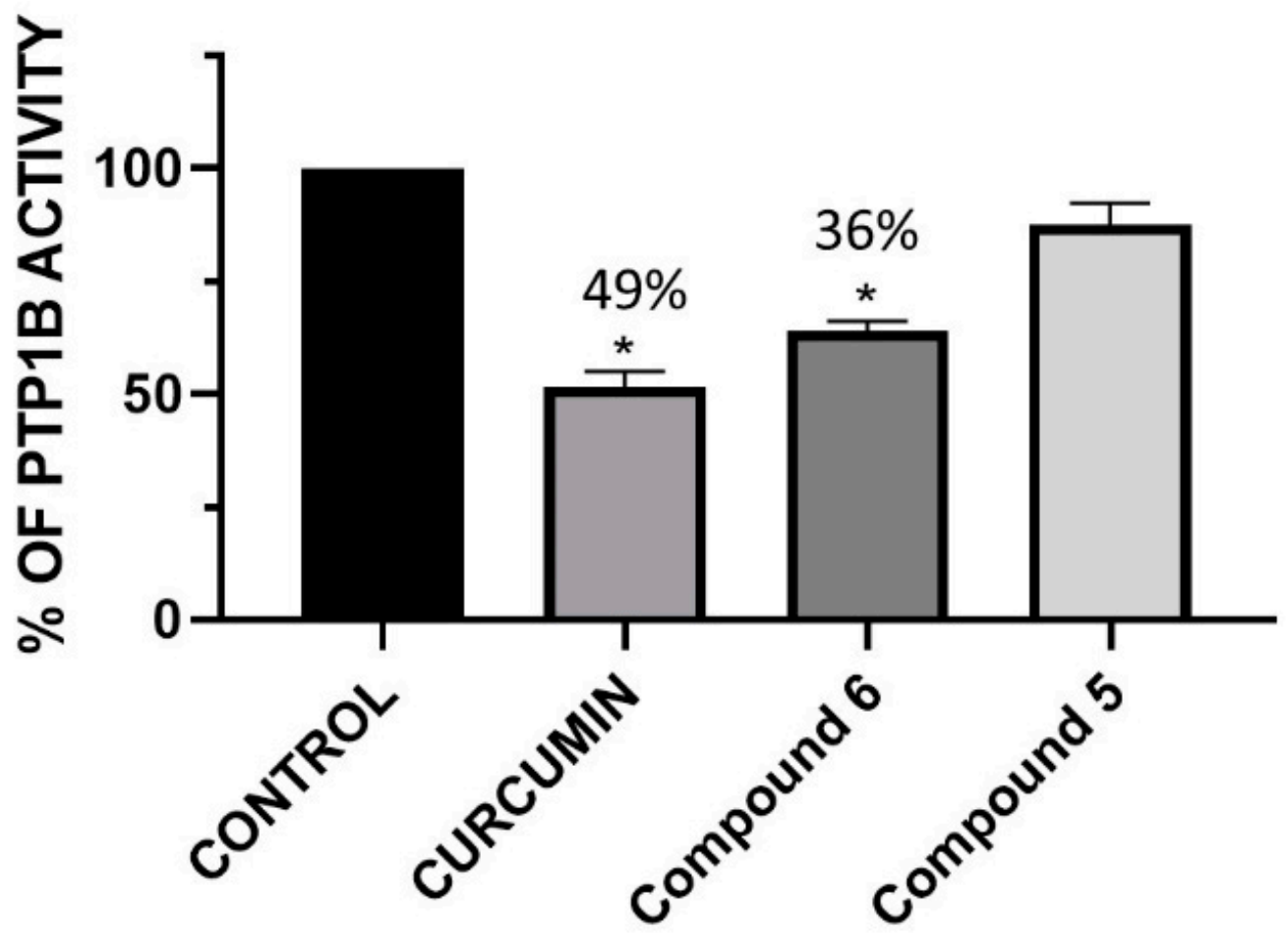

Figure 6. Enzymatic activity of PTP1B after $30 \mathrm{~min}$ of treatment with different concentrations of curcumin, compound 6 , and compound 5. The results were presented as a percentage of control as means $\pm \operatorname{SD}(n=3, * p<0.0001)$.

For the purpose of this research, we selected the PTP1B crystal structure 1T48, which was originally co-crystallized together with co BB3 ligand (benzbromarone derivative), bound in the allosteric site of the enzyme. First, we performed Induced-Fit docking (IFD) to evaluate the putative binding mode of compound $\mathbf{6}$. As a result, we obtained a complex with several molecular interactions between compound $\mathbf{6}$ and selected PTP1B amino acid residues (Figure 7a,b). The carbonyl group from the 1-methylpiperidin-4-one moiety of compound $\mathbf{6}$ formed an H-bond with the side chain of Asn193. The same interaction was observed between BB3 and PTP1B in the 1T48 crystal structure. Additionally, the second carbonyl group from compound $\mathbf{6}$ formed an H-bond with the main chain of Trp291. We also observed H-bond and $\pi$-cation interactions between Lys292 and the methyl phenyl carbonate fragment of compound $\mathbf{6}$. Those two amino acid residues were also involved in the formation of interactions in $1 \mathrm{~T} 48$, but their types were different $(\pi-\pi$ stacking and salt bridge, respectively). However, the presence of the same residues taking part in the proteinligand interaction of both the aforementioned ligands suggests an increased likelihood of high affinity of compound 6 to the allosteric site of PTP1B.

After basic evaluation of the obtained PTP1B-compound 6 complex, we redocked BB3. RMSD of redocked BB3 vs. the one from the crystal structure was $1.66 \AA^{2}$, which proves the good quality of the model we used (Figure 8a). 

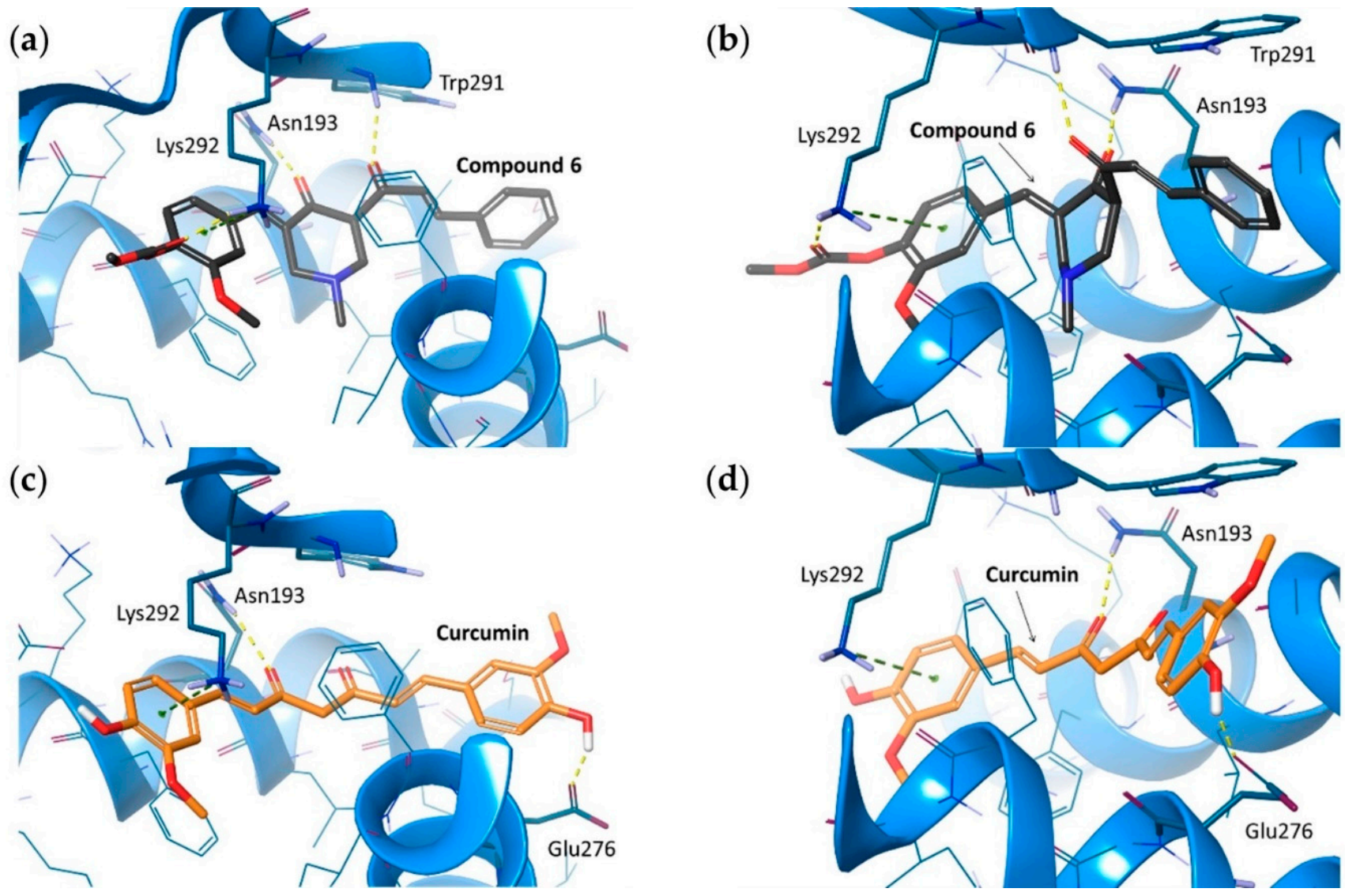

Figure 7. Molecular interactions formed between PTP1B (code 1T48) amino acid residues and its docked allosteric inhibitors: Compound $\mathbf{6}(\mathbf{a}, \mathbf{b})$ and curcumin $(\mathbf{c}, \mathbf{d})$. Amino acid residues within $5 \AA$ displayed as thin, blue sticks; amino acid residues engaged in ligand binding throughout $\mathrm{H}$-bonds (dotted yellow lines) and $\pi$-cation interaction (dotted green lines) displayed as bold, blue sticks.

(a)

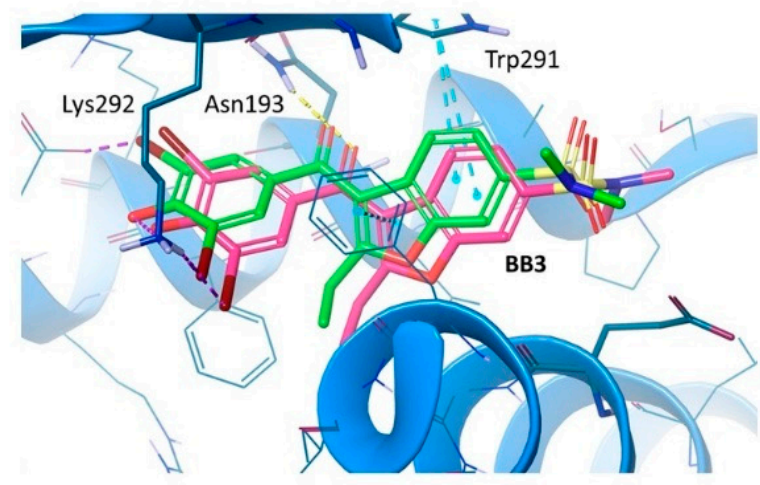

(b)

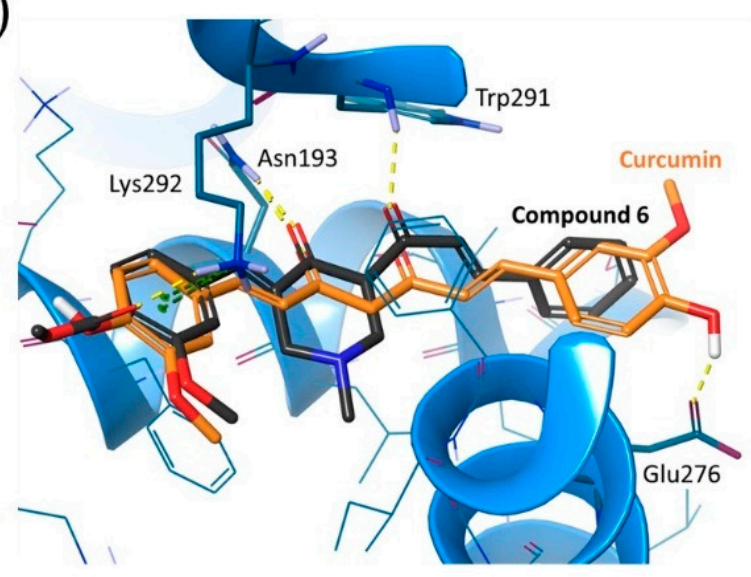

Figure 8. (a) Spatial orientation of BB3 within the allosteric site of PtP1B in the original crystal structure (PDB ID: 1T48; green ligand) and docked to the obtained, optimized model (pink ligand). RMSD obtained for BB3 redocking: $1.66 \AA$. CBR1 backbone displayed as blue ribbon. Amino acid residues engaged in ligand binding throughout H-bonds (dotted yellow lines), $\pi$-interactions (dotted blue lines), and halogen bonds (dotted purple lines) are displayed as sticks. (b) The predicted binding mode comparison of compound 6 (black) and curcumin (orange) within the allosteric site of PTP1B. Amino acid residues within $5 \AA$ displayed as thin, blue sticks; amino acid residues engaged in ligand binding throughout $\mathrm{H}$-bonds (dotted yellow lines) and $\pi$-cation interaction (dotted green lines) displayed as bold, blue sticks. 
Based on the obtained results, we used the described model to dock another allosteric PTP1B inhibitor-curcumin. As a result, we obtained a binding mode similar to the one observed for compound 6 (Figure 7c,d). Molecular interactions with Asn193 (H-bond) and Lys292 ( $\pi$-cation) were observed, with an additional H-bond between one of curcumin's phenolic groups and Glu276. The superposition of compound 6 and curcumin indicated a similar position of potential pharmacophore features (two H-bond acceptors and two aromatic rings) of both ligands within the PTP1B allosteric site (Figure 8b).

In the described docking simulations, we did not observe any interaction with Phe280 that was detected in 1 T48 but based on both in silico and in vitro results we assume that this interaction is not required for effective allosteric inhibition of PTP1B.

\section{Discussion}

The biggest threat and the main cause of cancer-related mortality is metastatic potential. After chemotherapy or radiotherapy, it is important to prevent the formation of a secondary tumor. The molecular mechanisms underlying metastasis are key to developing new strategies for the prevention and treatment of cancer.

PTP1B protein phosphatase is overexpressed in breast cancer cells, where it induces tumor growth by promoting the overexpression of growth factors and cytokines [36]. Researchers indicate that PTP may be a potential therapeutic target in the prevention and treatment of breast cancer [37]. It has not yet been established whether it is possible to treat advanced stages of human epidermal growth factor receptor 2 (HER2, Erb2, HER2/neu)positive breast cancer by inhibiting PTP1B. However, it was found that the deletion of PTP1B in mice reduces the risk or at least delays HER2/Neu-induced carcinogenesis, and overexpression of PTP1B in the mammary gland leads to the spontaneous development of breast cancer. PTP1B is involved in the control of Erb2-induced tumorigenesis of breast cancer by the attenuation of mitogen-activated protein kinases (MAP, MAPK) and Akt pathways [38].

In studies comparing neoplastic cells to healthy ones, PTP1B overexpression in tumor cells is significant. Researchers point to a correlation of tumor size and lymph node metastasis in patients who have higher levels of PTP1B [39]. PTP1B promotes invasion and metastasis by regulating the PTEN-AKT/pAKT pathway and promoting the expression of metalloproteinase 2 (MMP2) and MMP7, which is associated with lymph node metastasis. In addition, it was noted that the impact of PTP1B on phosphatase and the tensin homolog was the deletion of chromosome ten (PTEN), accompanied with an abatement of AKT phosphorylation [40]. Moreover, PTP1B dephosphorylates the signal transducer and activator of transcription 3 (STAT3), which in turn increases C-C motif chemokine ligand 5 (CCL5) expression responsible for the invasion of cancer cells [39].

Many studies have shown that PTP1B can act as an activator of the Src kinase, which may result in increasing tumorigenicity and promoting tumor progression. Non-receptor tyrosine kinase Src is deregulated in multiple tumor types. The crucial role of Src kinases in tumor development involves the effect of Src on proliferation, survival, adhesion, migration, invasion, and metastasis. Src kinase activity has been reported to be highly elevated in many human cancer cell lines, e.g., breast cancer, lung cancer, and colon cancer cells [41-45]. Moreover, studies of several human breast cancer cell lines with increased Src kinase activity have shown higher levels of the PTP1B protein relative to healthy breast epithelial cells. There are two main Src phosphorylation sites: The Cys419 autophosphorylation site and the Cys530 C-terminal phosphorylation site. PTP1B dephosphorylates Src kinase and, through activation, controls its pro-oncogenic effect. Acting together, they contribute to the development and progression of breast cancer [46].

PTPs play an important part in cell signaling. Moreover, they can be indicative of the reactive oxygen species (ROS) level because reversible oxidation is the main mechanism of control of PTPs activity. A ROS level higher than normal is one of the reasons for cancer development and progression [47]. Several studies suggest that the production of reactive oxygen species associated with oxidative stress may lead to the inactivation of protein 
tyrosine phosphatases. In addition, reversible oxidation of catalytic cysteine is suggested to be a major regulatory mechanism of PTPs activity [48]. Generally, reversible oxidation of the thiol moiety to sulfenic acid is a biological process commonly used to control the functions of many proteins. These thiol groups containing proteins play an important role in cell signaling (e.g., PTP1B), binding transcription factors to DNA (e.g., Nrf-2, NF- $k \beta$ ), and other regulatory processes [49]. Due to high vulnerability to oxidation and relatively easy activity measurement, PTPs may be used as extremely sensitive biosensors of oxidative stress levels. Thereupon, the role of PTPs in the genesis of cancers may partly result from the increased level of ROS in tumor cells compared to healthy cells, which leads to impaired regulation of PTPs by oxidation [50]. Furthermore, overexpression of the protein Nox1 producing reactive oxygen species can cause cellular transformation and tumorigenesis, confirming the participation of ROS in cancer development [51].

In this study, we examined the cytotoxicity effect on breast cancer cells in correlation to different places of substitution on aromatic rings relative to the piperazine ring in curcumin derivatives. The compounds synthesized by our group are characterized by the free $-\mathrm{OH}$ group or blocked by carbonic acid ester. The main reason for the study of the activity of derivatives with a protected hydroxyl group was to reduce the metabolism of the proposed substances, which is described as one of the main (next to poor water solubility) factors limiting bioavailability and, as a result, the use of curcumin in medicine. Literature data indicate that curcumin sulfates(VI) and glucuronates linked to the curcumin phenol group are the major metabolites of curcumin [52]. Blocking the phenol group in the tested derivatives caused them to slow down their metabolism, enabling the use of a smaller dose of the substance to induce a cytotoxic effect. We observed that compounds $\mathbf{5}$ and $\mathbf{6}$ were better cytotoxicity agents than other derivatives. It is worth emphasizing that these compounds are characterized by substitution in the aromatic ring proximal to the piperazine ring and that the difference between these compounds was the protection of the $-\mathrm{OH}$ group at position 4 of the aromatic ring. This protection caused compound 6 to show high antioxidant effectiveness in a low concentration (scavenging $6 \%$ in concentration $0.05 \mu \mathrm{M}$ ), higher cytotoxicity potential against triple-negative breast cancer, and the generation of a higher level of ROS. Moreover, the higher level of ROS correlated with the lower level of PTP1B in MDA-MB-231 cell lysates. On the other hand, in silico studies showed that compound 6 could be an allosteric inhibitor of PTP1B. Curcumin is indicated as a pan-assay interference compound (PAINS) [53], which means it gives false positive results against numerous proteins. In our research, the synthesized derivatives did not show this effect. Furthermore, in the recombinant PTP1B assay, we observed that compound 6 caused an inhibitory effect in a concentration of $100 \mu \mathrm{M}$.

\section{Materials and Methods}

\subsection{Chemicals and Reagents}

$N$-Methyl-4-piperidone, Benzaldehyde, Diisopropylamine, $n$-Butyllithium (2.5 M solution in hexanes), 4-(Dimethylamino)pyridine (DMAP), and Sodium bicarbonate were purchased from Merck. Acetic acid, Dichloromethane, Tetrahydrofuran, Ethanol, Ethyl acetate, Citric acid, Sodium Sulfate(VI), and Acetic anhydride were purchased from $\mathrm{POCH}$, Gliwice, Poland. Vanilin was purchased from Acros, Waltham, Massachusetts, USA. Dimethyl-sulfoxide (DMSO), Potassium superoxide, 18-crown-6-ether, Nitro blue tetrazolium chloride (NBT), Curcumin, Fetal bovine serum (FBS), 3-(4,5-dimethylthiazol2-yl)-2,5-diphenyltetrazolium bromide (MTT), recombinant PTP1B phosphatase, paranitrophenyl phosphate ( $p$ NPP), and $2^{\prime}, 7^{\prime}$-dichlorofluorescein were purchased from SigmaAldrich, Saint Louis, Missouri, USA. Dulbecco's Modified Eagle's Medium (DMEM) and Phosphate-buffered saline (PBS) were purchased from PAN-biotech, Aidenbach, Germany. Lastly, 4-20\% MP TGX Tain-Free Gel 10W was purchased from Bio-Rad Laboratories, Hercules, CA, USA and PTP1B antibodies were purchased from Cell Signaling, Danvers, MA, USA. 


\subsection{Synthesis}

\subsubsection{General Information}

The ${ }^{1} \mathrm{H}$ and ${ }^{13} \mathrm{C}$ NMR spectra were recorded on a Bruker AVANCE II 400 spectrometer (Bruker, Fallanden, Switzerland) at $400 \mathrm{MHz}$ for ${ }^{1} \mathrm{H}$ and $100 \mathrm{MHz}$ for ${ }^{13} \mathrm{C}$ NMR spectra. The chemical shifts are reported relative to tetramethylsilane (TMS) and were referenced to the $\mathrm{CDCl}_{3}$ signals at $\delta=7.26$ for ${ }^{1} \mathrm{H}$ and $\delta=77.0$ for ${ }^{13} \mathrm{C}$ spectra. IR spectra were recorded on the Nicolet 6700 (Thermo Scientific, Waltham, Massachusetts, USA); the Attenuated Total Reflectance (ATR) method was used. The EZ-Melt MPA120 apparatus (Stanford Research Systems, Sunnyvale, California, USA) was used to measure melting points. An LC-MS system consisting of 1290 Infinity UHPLC coupled to a 6545 Q-TOF-MS detector (Agilent, Santa Clara, CA, USA) or Micromass LCT 298 TOF (Waters, Milford, MA, USA) was used to record high-resolution mass spectra (accurate mass analysis). The analyses were carried out in a positive ion mode. Air-sensitive reactions were carried out under argon in flame-dried Schlenk tubes. Dichloromethane (DCM) and diisopropylamine (DIPA) were distilled from $\mathrm{CaH}_{2}$. Tetrahydrofuran (THF) was dried by distillation from sodium benzophenone ketyl under argon. The commercially available reagents were used without purification. Flash Column Chromatography (FCC) was performed on Silica gel 230-400 mesh from Fluka. The reagents used in the synthesis were commercially available or were synthesized by methods from the literature (a reference to their synthesis is given).

\subsubsection{Synthesis of the Compounds}

(3E)-3-[(4-Hydroxy-3-methoxyphenyl)methylidene]-1-methylpiperidin-4-one (1) is a commercially available compound (from Aurora Fine Chemicals).

(E)-2-Methoxy-4-((1-methyl-4-oxopiperidin-3-ylidene)methyl)phenyl methyl carbonate (2) and dimethyl $\left(\left(\left(1 E, 1^{\prime} E\right)-(1-m e t h y l-4-o x o p i p e r i d i n e-3,5-d i y l i d e n e) b i s(m e t h a n e y l y l i d e n e)\right)\right.$ bis(2-methoxy-4,1-phenylene)) bis(carbonate) (10).

To a dry, argon-filled Schlenk tube, anhydrous THF $(100 \mathrm{~mL})$ and diisopropyl amine $\left(6.21 \mathrm{~mL}, 44.0 \mathrm{mmol}\right.$ ) were added. The solution was cooled to $0{ }^{\circ} \mathrm{C}$ and then $n$-butyllithium was added ( $2.5 \mathrm{M}$ solution in hexanes, $17.6 \mathrm{~mL}, 44.0 \mathrm{mmol})$. After $30 \mathrm{~min}, \mathrm{~N}$-methyl4-piperidone $(4.92 \mathrm{~mL}, 40.0 \mathrm{mmol})$ was added dropwise to the reaction. The reaction was stirred at $0{ }^{\circ} \mathrm{C}$ for $60 \mathrm{~min}$ and then cooled to $-78{ }^{\circ} \mathrm{C}$ and stirred for an additional $15 \mathrm{~min}$, then a solution of 3-methoxy-4-methoxycarbonyloxy-benzaldehyde (10.089 g, $48.0 \mathrm{mmol}$ ) [54] in dry THF $32.0 \mathrm{~mL}$ was added via cannula. After $30 \mathrm{~min}$, the reaction was terminated by the addition of $20 \mathrm{~mL}$ of a saturated aqueous solution of $\mathrm{NaHCO}_{3}$, and after a minute. $10 \mathrm{~mL}$ of a $10 \%$ water solution of citric acid was added, to avoid hydrolysis of the carbamate. After heating to room temperature, $100 \mathrm{~mL}$ of water was added, and the mixture was extracted with dichloromethane $(4 \times 50 \mathrm{~mL})$. Combined organic extracts were dried over $\mathrm{Na}_{2} \mathrm{SO}_{4}$ and concentrated under a vacuum. The crude product was dissolved in dry DCM $(100 \mathrm{~mL})$. Acetic anhydride $(6.0 \mathrm{~mL}, 63.5 \mathrm{mmol})$ and 4-(dimethylamino)pyridine $(0.195 \mathrm{~g}, 1.60 \mathrm{mmol})$ were added to the solution. The reaction was stirred for $2 \mathrm{~h}$ at room temperature, then acetic acid $(99 \%, 8 \mathrm{~mL})$ was added to cause the elimination of the formed ester. After $15 \mathrm{~min}$, the mixture was pureed in $30 \mathrm{~mL}$ of cold water cooled to $0{ }^{\circ} \mathrm{C}$, and the saturated aqueous solution of $\mathrm{NaHCO}_{3}$ was added to neutral $\mathrm{pH}$. The formed mixture was extracted with DCM $(4 \times 50 \mathrm{~mL})$. Combined extracts were dried over $\mathrm{Na}_{2} \mathrm{SO}_{4}$ and evaporated under a vacuum. The residue was purified by flash column chromatography (EtOH:DCM:AcOEt, 5:25:70) to afford the products 2 (3.569 g, 29\%) as a white solid and 10 $(2.822 \mathrm{~g}, 14 \%)$ as a pale yellow solid.

(E)-2-Methoxy-4-((1-methyl-4-oxopiperidin-3-ylidene)methyl)phenyl methyl carbonate (2)

Mp: $116.0-118.0{ }^{\circ} \mathrm{C} ;{ }^{1} \mathrm{H}$ NMR $\left(400 \mathrm{MHz}, \mathrm{CDCl}_{3}\right): \delta=7.50(\mathrm{~s}, 1 \mathrm{H}), 7.14(\mathrm{~d}, J=8.1 \mathrm{~Hz}$, $1 \mathrm{H}), \quad 6.94-6.87 \quad(\mathrm{~m}, 2 \mathrm{H}), 3.90(\mathrm{~s}, 3 \mathrm{H}), 3.84(\mathrm{~s}, 3 \mathrm{H}), 3.62(\mathrm{~s}, 2 \mathrm{H}), 2.80(\mathrm{t}$, $J=6.2 \mathrm{~Hz}, 2 \mathrm{H}), 2.65(\mathrm{t}, J=6.2 \mathrm{~Hz}, 2 \mathrm{H}), 2.42(\mathrm{~s}, 3 \mathrm{H}) \mathrm{ppm} ;{ }^{13} \mathrm{C} \mathrm{NMR}\left(100 \mathrm{MHz}, \mathrm{CDCl}_{3}\right)$ : $\delta=197.44,153.52,150.96,140.36,134.86,133.94,133.27,122.43,122.30,114.62,57.46,55.91$, 55.54, 52.60, 46.03, 38.94 ppm; FTIR (ATR, ṽ): 2943, 1752, 1669, 1596, 1514, 1442, $1315 \mathrm{~cm}^{-1}$; HRMS (ESI): calcd. for: $\mathrm{C}_{16} \mathrm{H}_{20} \mathrm{NO}_{5}[\mathrm{M}+\mathrm{H}]^{+}$306.1336; found 306.13416 . 
Dimethyl (((1E,1'E)-(1-methyl-4-oxopiperidine-3,5-diylidene) bis(methaneylylidene)) bis(2-methoxy-4,1-phenylene)) bis(carbonate) (10)

Mp: $154.0-157.0{ }^{\circ} \mathrm{C} ;{ }^{1} \mathrm{H}$ NMR $\left(400 \mathrm{MHz} \mathrm{CDCl}_{3}\right): \delta=7.74(\mathrm{~s}, 2 \mathrm{H}), 7.17(\mathrm{~d}, J=8.2 \mathrm{~Hz}$, $2 \mathrm{H}), 7.00-6.94(\mathrm{~m}, 4 \mathrm{H}), 3.91(\mathrm{~s}, 6 \mathrm{H}), 3.87(\mathrm{~s}, 6 \mathrm{H}), 3.74(\mathrm{~s}, 4 \mathrm{H}), 2.45(\mathrm{~s}, 3 \mathrm{H}) \mathrm{ppm} ;{ }^{13} \mathrm{C} \mathrm{NMR}$ $\left(100 \mathrm{MHz}_{\mathrm{CDCl}}\right): \delta=186.47,153.54,151.00,140.36,135.56,134.25,133.28,122.42,122.34$, 114.64, 77.00, 56.80, 55.92, 55.56, 45.61 ppm; FTIR (ATR, v): 2950, 1754, 1687, 1601, 1517, 1439, $1315,1266 \mathrm{~cm}^{-1}$; HRMS (ESI): calcd. for: $\mathrm{C}_{26} \mathrm{H}_{28} \mathrm{NO}_{9}[\mathrm{M}+\mathrm{H}]^{+} 498.1759$; found 498.17412 .

(E)-2-Methoxy-4-(3-(1-methyl-4-oxopiperidin-3-yl)-3-oxoprop-1-en-1-yl)phenyl methyl carbonate (3)

Typical procedure 1 for acylation of piperydone and $\alpha, \beta$-unsaturated piperydones.

To a dry, argon-filled Schlenk tube, anhydrous THF (50 mL) and diisopropyl amine $(1.05 \mathrm{~mL}, 7.41 \mathrm{mmol})$ were added. The solution was cooled to $0{ }^{\circ} \mathrm{C}$ and then $n$-butyllithium was added (2.5 M solution in hexanes, $2.97 \mathrm{~mL}, 7.41 \mathrm{mmol})$. After $30 \mathrm{~min}, \mathrm{~N}$-methyl-4piperidone $(0.83 \mathrm{~mL}, 6.74 \mathrm{mmol})$ was added dropwise to the reaction. The reaction was mixed at $0{ }^{\circ} \mathrm{C}$ for $60 \mathrm{~min}$ and then cooled to $-78{ }^{\circ} \mathrm{C}$, and after an additional $15 \mathrm{~min}$, a solution of (E)-4-(3-cyano-3-oxoprop-1-en-1-yl)-2-methoxyphenyl methyl carbonate (1.936 g, $7.41 \mathrm{mmol})$ in dry THF $(10 \mathrm{~mL})$ was added. The reaction was stirred at $-78{ }^{\circ} \mathrm{C}$ for $30 \mathrm{~min}$ and then quenched with a $10 \%$ aqueous solution of citric acid $(15 \mathrm{~mL})$. The reaction mixture was pureed in water $(100 \mathrm{~mL})$ and extracted with dichloromethane $(4 \times 50 \mathrm{~mL})$. The combined organic extracts were dried with $\mathrm{Na}_{2} \mathrm{SO}_{4}$, filtered, and concentrated under a vacuum. The product was predicated by flash column chromatography (EtOH:DCM:AcOEt, 5:25:70) to yield a white solid (1.192 $\mathrm{g}, 51 \%)$.

Mp: $113-115{ }^{\circ} \mathrm{C} ;{ }^{1} \mathrm{H} \mathrm{NMR}\left(400 \mathrm{MHz} \mathrm{CDCl}_{3}\right): \delta=16.46(\mathrm{~s}, 1 \mathrm{H}), 7.67(\mathrm{~d}, J=15.5 \mathrm{~Hz}$, $1 \mathrm{H}), 7.25-7.03(\mathrm{~m}, 5 \mathrm{H}), 6.66(\mathrm{~d}, J=15.5 \mathrm{~Hz}, 1 \mathrm{H}), 3.91(\mathrm{~s}, 3 \mathrm{H}), 3.90(\mathrm{~s}, 3 \mathrm{H}), 3.41(\mathrm{~s}, 2 \mathrm{H}), 2.67$ $(\mathrm{t}, J=5.8 \mathrm{~Hz}, 2 \mathrm{H}), 2.59(\mathrm{t}, J=5.8 \mathrm{~Hz}, 2 \mathrm{H}), 2.49(\mathrm{~s}, 3 \mathrm{H}) \mathrm{ppm} ;{ }^{13} \mathrm{C} \mathrm{NMR}\left(100 \mathrm{MHz}, \mathrm{CDCl}_{3}\right)$ : $\delta=191.63,177.57,153.48,151.36,141.36,140.88,134.28,122.74,120.57,119.04,112.14,105.83$, 56.02, 55.59, 53.32, 51.29, 46.02, 34.18 ppm; FTIR (ATR, v): 2945, 2837, 1763, 1629, 1597, 1512, $1439,1253 \mathrm{~cm}^{-1}$; HRMS (ESI): calcd. for: $\mathrm{C}_{18} \mathrm{H}_{22} \mathrm{NO}_{6}[\mathrm{M}+\mathrm{H}]^{+} 348.1442$; found 348.14356 .

3-((E)-benzylidene)-5-cinnamoyl-1-methylpiperidin-4-one (4)

Compound 4 was prepared according to Typical procedure 1 from $(E)$-3-benzylideno1-metylopiperyd-4-one $(0.392 \mathrm{~g}, 1.95 \mathrm{mmol})$ [55] and (E)-cinnamoyl cyanide (0.346 g, $2.2 \mathrm{mmol}$ ) [25] and purified by flash column chromatography (AcOEt:Hex, 30:70) to yield a pink solid $(0.588 \mathrm{~g}, 91 \%)$.

Mp: $115-118{ }^{\circ} \mathrm{C} ;{ }^{1} \mathrm{H}$ NMR $\left(400 \mathrm{MHz} \mathrm{CDCl}_{3}\right): \delta=16.79(\mathrm{~s}, 1 \mathrm{H}), 7.80(\mathrm{~d}, J=15.5 \mathrm{~Hz}$, $1 \mathrm{H}), 7.75(\mathrm{~s}, 1 \mathrm{H}), 7.63-7.58(\mathrm{~m}, 2 \mathrm{H}), 7.46-7.33(\mathrm{~m}, 8 \mathrm{H}), 6.90(\mathrm{~d}, J=15.5 \mathrm{~Hz}, 1 \mathrm{H}), 3.62(\mathrm{~s}$, 2H), 3.58 (s, 2H), 2.51 (s, 3H) ppm; $\left.{ }^{13} \mathrm{C} \mathrm{NMR} \mathrm{(100} \mathrm{MHz,} \mathrm{CDCl}_{3}\right): \delta=182.36,177.33,142.30$, 135.32, 134.85, 133.27, 130.28, 130.20, 129.90, 128.77, 128.46, 128.34, 128.20, 119.27, 106.87, 54.82, 53.07, 45.34 ppm; FTIR (ATR, $\tilde{\mathrm{v}}$ ): 3063, 2755, 1619, 1575, 1545, 1441,1411, $1288 \mathrm{~cm}^{-1}$; HRMS (ESI): calcd. for: $\mathrm{C}_{22} \mathrm{H}_{22} \mathrm{NO}_{2}[\mathrm{M}+\mathrm{H}]^{+} 332.1645$; found 332.1650.

4-((E)-3-(5-((E)-Benzylidene)-1-methyl-4-oxopiperidin-3-yl)-3-oxoprop-1-en-1-yl)-2methoxyphenyl methyl carbonate $(8)$

Compound 8 was prepared according to Typical procedure 1 from $(E)$-3-benzylidene1-methylpiperidin-4-one (1.610 g, $8.0 \mathrm{mmol}$ ) [51] and (E)-4-(3-cyano-3-oxoprop-1-en-1-yl)2-methoxyphenyl methyl carbonate $(1.841 \mathrm{~g}, 7.0 \mathrm{mmol})$ [25] and purified by flash column chromatography (AcOEt:Toluene, 50:50) to yield a pink solid (2.470 g, 81\%).

Mp: $130-131{ }^{\circ} \mathrm{C} ;{ }^{1} \mathrm{H}$ NMR $\left(400 \mathrm{MHz}, \mathrm{CDCl}_{3}\right): \delta=16.81(\mathrm{~s}, 1 \mathrm{H}), 7.73(\mathrm{~s}, 1 \mathrm{H}), 7.71(\mathrm{~d}$, $J=15.5 \mathrm{~Hz}, 1 \mathrm{H}), 7.41-7.32(\mathrm{~m}, 5 \mathrm{H}), 7.19-7.10(\mathrm{~m}, 3 \mathrm{H}), 6.80(\mathrm{~d}, J=15.5 \mathrm{~Hz}, 1 \mathrm{H}), 3.91$ (s, 3H), 3.90 (s, 3H), 3.59 (s, 2H), 3.54 (s, 2H), 2.49 (s, 3H) ppm; ${ }^{13} \mathrm{C} \mathrm{NMR} \mathrm{(100} \mathrm{MHz,} \mathrm{CDCl} \mathrm{N}_{3}$ ): $\delta=181.80,177.85,153.44,151.33,141.42,141.37,135.37,134.20,133.40,130.47,129.97,128.53$, $128.39,122.71,120.73,119.77,112.16,107.09,55.97,55.56,55.02,53.21,45.54$ ppm; FTIR (ATR, $\tilde{\mathrm{V}}): 2935,1766,1620,1587,1506,1438,1416,1249 \mathrm{~cm}^{-1}$; HRMS (ESI): calcd. for: $\mathrm{C}_{25} \mathrm{H}_{26} \mathrm{NO}_{6}$ $[\mathrm{M}+\mathrm{H}]^{+}$436.1755; found 436.17546 .

4-((E)-(5-Cinnamoyl-1-methyl-4-oxopiperidin-3-ylidene)methyl)-2-methoxyphenyl methyl carbonate (6) 
Compound $\mathbf{6}$ was prepared according to Typical procedure 1 from $\mathbf{2}(2.451 \mathrm{~g}, 8.0 \mathrm{mmol})$ and (E)-cinnamoyl cyanide (1.392 $\mathrm{g}, 8.8 \mathrm{mmol})$ [25] and purified by flash column chromatography (AcOEt:Toluene, 40:60) to yield a pink solid (1.982 g, 57\%).

Mp: $134-135{ }^{\circ} \mathrm{C} ;{ }^{1} \mathrm{H}$ NMR $\left(400 \mathrm{MHz}, \mathrm{CDCl}_{3}\right): \delta=16.74(\mathrm{~s}, 1 \mathrm{H}), 7.80(\mathrm{~d}, J=15.5 \mathrm{~Hz}$, $1 \mathrm{H}), 7.69(\mathrm{~s}, 1 \mathrm{H}), 7.63-7.58(\mathrm{~m}, 2 \mathrm{H}), 7.42-7.37(\mathrm{~m}, 3 \mathrm{H}), 7.18(\mathrm{~d}, J=8.1 \mathrm{~Hz}, 1 \mathrm{H}), 6.96-6.87$ $(\mathrm{m}, 3 \mathrm{H}), 3.94(\mathrm{~s}, 3 \mathrm{H}), 3.89(\mathrm{~s}, 3 \mathrm{H}), 3.60(\mathrm{~s}, 2 \mathrm{H}), 3.58(\mathrm{~s}, 2 \mathrm{H}), 2.51(\mathrm{~s}, 3 \mathrm{H}) \mathrm{ppm} ;{ }^{13} \mathrm{C}$ NMR $\left(100 \mathrm{MHz}, \mathrm{CDCl}_{3}\right): \delta=182.74,176.87,153.61,150.92,142.49,139.98,134.88,134.64,132.18$, $130.96,130.29,128.83,128.26,122.23,122.12,119.30,114.18,107.18,55.90,55.54,54.89,53.23$, 45.53 ppm; FTIR (ATR, v): 2935, 1763, 1624, 1598, 1577, 1511, 1446, 1408, 1315, $1288 \mathrm{~cm}^{-1}$, HRMS (ESI): calcd. for: $\mathrm{C}_{25} \mathrm{H}_{26} \mathrm{NO}_{6}[\mathrm{M}+\mathrm{H}]^{+} 436.1755$; found 436.17576 .

2-Methoxy-4-((E)-(5-((E)-3-(3-methoxy-4-((methoxycarbonyl)oxy)phenyl)acryloyl)-1methyl-4-oxopiperidin-3-ylidene)methyl)phenyl methyl carbonate (12)

Compound 12 was prepared according to Typical procedure 1 from $2(2.110 \mathrm{~g}, 6.9 \mathrm{mmol})$ and (E)-4-(3-cyano-3-oxoprop-1-en-1-yl)-2-methoxyphenyl methyl carbonate (1.983 g, $7.59 \mathrm{mmol}$ ) [25] and purified by flash column chromatography (MeOH:DCM; 5:95) to yield a pink solid $(1.325 \mathrm{~g}, 36 \%)$.

Mp: $104-108{ }^{\circ} \mathrm{C} ;{ }^{1} \mathrm{H}$ NMR $\left(400 \mathrm{MHz}, \mathrm{CDCl}_{3}\right): \delta=16.74(\mathrm{~s}, 1 \mathrm{H}), 7.71(\mathrm{~d}, J=15.5 \mathrm{~Hz}$, $1 \mathrm{H}), 7.66(\mathrm{~s}, 1 \mathrm{H}), 7.20-7.11(\mathrm{~m}, 4 \mathrm{H}), 6.94-6.89(\mathrm{~m}, 2 \mathrm{H}), 6.79(\mathrm{~d}, J=15.5 \mathrm{~Hz}, 1 \mathrm{H}), 3.92(\mathrm{~s}, 3 \mathrm{H})$, $3.91(\mathrm{~s}, 3 \mathrm{H}), 3.90(\mathrm{~s}, 3 \mathrm{H}), 3.86(\mathrm{~s}, 3 \mathrm{H}), 3.57(\mathrm{~s}, 2 \mathrm{H}), 3.54(\mathrm{~s}, 2 \mathrm{H}), 2.49(\mathrm{~s}, 3 \mathrm{H}) \mathrm{ppm} ;{ }^{13} \mathrm{C}$ NMR $\left(100 \mathrm{MHz}, \mathrm{CDCl}_{3}\right): \delta=182.16,177.34,153.62,153.45,151.36,150.95,141.57,141.48,140.04$, 134.63, 134.17, 132.38, 130.99, 122.74, 122.26, 122.16, 120.75, 119.75, 114.22, 112.21, 107.24, 55.99, 55.93, 55.57, 55.55, 54.95, 53.21, 45.54 ppm; FTIR (ATR, r) ): 2949, 2839, 1761, 1618, $1507,1438,1250,1204,1159 \mathrm{~cm}^{-1}$; HRMS (ESI): calcd. for: $\mathrm{C}_{28} \mathrm{H}_{30} \mathrm{NO}_{10}[\mathrm{M}+\mathrm{H}]^{+} 540.1864$; found 540.18483 .

3-Cinnamoyl-5-((E)-4-hydroxy-3-methoxybenzylidene)-1-methylpiperidin-4-one (5) Typical procedure 2 for the hydrolysis of carbamate protective group.

To compound 6 (0.085 g, $0.195 \mathrm{mmol})$, methanol $(2 \mathrm{~mL})$ and DCM were added in amounts for complete dissolution $(3 \mathrm{~mL})$. The solution was cooled to $0{ }^{\circ} \mathrm{C}$, then a solution of ammonia in water $(10 \%, 1 \mathrm{~mL})$ was added after $20 \mathrm{~min}$. The reaction was heated to room temperature and left overnight (monitored by TLC). The next day, $20 \mathrm{~mL}$ of water and a $10 \%$ water solution of citric acid to $\mathrm{pH}=5$ were added. The obtained mixture was extracted with $\mathrm{DCM}(3 \times 20 \mathrm{~mL})$, and the combined organic extracts were dried over filtered $\mathrm{Na}_{2} \mathrm{SO}_{4}$ and concentrated under vacuum. The product was predicated by flash column chromatography (EtOH:DCM:AcOEt; 2:28:70) to yield an orange solid (0.046 g, 62\%).

Mp: $145-147^{\circ} \mathrm{C} ;{ }^{1} \mathrm{H}$ NMR $\left(400 \mathrm{MHz}, \mathrm{CDCl}_{3}\right): \delta=16.92(\mathrm{~s}, 1 \mathrm{H}), 7.77(\mathrm{~d}, J=15.5 \mathrm{~Hz}$, $1 \mathrm{H}), 7.67(\mathrm{~s}, 1 \mathrm{H}), 7.61-7.57(\mathrm{~m}, 2 \mathrm{H}), 7.42-7.37(\mathrm{~m}, 3 \mathrm{H}), 6.95-6.85(\mathrm{~m}, 4 \mathrm{H}), 6.37(\mathrm{~s}, 1 \mathrm{H}), 3.88(\mathrm{~s}$, $3 \mathrm{H}), 3.64(\mathrm{~s}, 2 \mathrm{H}), 3.58(\mathrm{~s}, 2 \mathrm{H}), 2.52(\mathrm{~s}, 3 \mathrm{H}) \mathrm{ppm} ;{ }^{13} \mathrm{C} \mathrm{NMR}\left(100 \mathrm{MHz}, \mathrm{CDCl}_{3}\right): \delta=181.20$, $178.74,146.66,146.53,141.99,135.09,133.91,130.20,128.88,128.51,128.24,127.83,123.86$, 119.34, 114.66, 113.05, 106.62, 55.87, 55.28, 53.20, 45.50. ppm; FTIR (ATR, v): 3001, 2949, 2910, 1617, 1575, 1509, 1446, 1422, 1289, 1277, 1132, $1120 \mathrm{~cm}^{-1}$; HRMS (ESI): calcd. for: $\mathrm{C}_{23} \mathrm{H}_{24} \mathrm{NO}_{4}[\mathrm{M}+\mathrm{H}]^{+}$378.1700; found 378.17102. 4-one (7)

(E)-3-Benzylidene-5-((E)-3-(4-hydroxy-3-methoxyphenyl)acryloyl)-1-methylpiperidin-

Compound 7 was prepared according to Typical procedure 2 from $8(1.151 \mathrm{~g}, 2.64 \mathrm{mmol})$ and purified by flash column chromatography (EtOH:DCM:AcOEt; 2:28:70) to yield a pink solid ( $0.477 \mathrm{~g}, 48 \%)$.

Mp: $172-174{ }^{\circ} \mathrm{C} ;{ }^{1} \mathrm{H}$ NMR $\left(400 \mathrm{MHz}, \mathrm{CDCl}_{3}\right): \delta=16.88(\mathrm{~s}, 1 \mathrm{H}), 7.78-7.69(\mathrm{~m}, 2 \mathrm{H})$, 7.45-7.39 (m, 2H), 7.38-7.30 (m, 3H), $7.19(\mathrm{dd}, J=8.3,1.9 \mathrm{~Hz}, 1 \mathrm{H}), 7.05(\mathrm{~d}, J=1.9 \mathrm{~Hz}, 1 \mathrm{H})$, $6.94(\mathrm{~d}, J=8.2 \mathrm{~Hz}, 1 \mathrm{H}), 6.72(\mathrm{~d}, J=15.4 \mathrm{~Hz}, 1 \mathrm{H}), 6.15(\mathrm{br} \mathrm{s}, 1 \mathrm{H}) 3.96(\mathrm{~s}, 3 \mathrm{H}), 3.62(\mathrm{~s}, 2 \mathrm{H}), 3.58$ $(\mathrm{s}, 2 \mathrm{H}), 2.51(\mathrm{~s}, 3 \mathrm{H}) \mathrm{ppm} ;{ }^{13} \mathrm{C} \mathrm{NMR}\left(100 \mathrm{MHz}, \mathrm{CDCl}_{3}\right): \delta=183.50,176.27,148.41,146.95$, $142.99,135.55,133.00,130.34,129.94,128.44,128.41,127.45,122.92,116.74,115.11,110.39$, 106.59, 55.93, 54.89, 53.25, 45.43 ppm; FTIR (ATR, $\tilde{\mathrm{v}}):$ 2916, 1617, 1590, 1577, 1506, 1426, 1270, $1158,1121 \mathrm{~cm}^{-1}$; HRMS (ESI): calcd. for: $\mathrm{C}_{23} \mathrm{H}_{24} \mathrm{NO}_{4}[\mathrm{M}+\mathrm{H}]^{+} 378.1700$; found 378.17111. 
(3E,5E)-5-(4-Hydroksy-3-metoksybenzylideno)-3-[3-(4-hydroksy-3-metoksy)prop2-enylo]-1-metylopiperyd-4-on (11)

Compound 11 was prepared according to Typical procedure 2 from 12 (0.065 g, $0.12 \mathrm{mmol}$ ) and purified by flash column chromatography (EtOH/DCM/AcOEt, 5:25:70) followed by recrystallization from DCM to yield a pink solid $(0.018 \mathrm{~g}, 35 \%)$.

Mp: $174-176{ }^{\circ} \mathrm{C} ;{ }^{1} \mathrm{H}$ NMR $\left(400 \mathrm{MHz} \mathrm{CDCl}_{3}\right): \delta=16.98(\mathrm{~s}, 1 \mathrm{H}), 7.72(\mathrm{~d}, J=15.4 \mathrm{~Hz}$, $1 \mathrm{H}), 7.66(\mathrm{~s}, 1 \mathrm{H}), 7.21-7.18(\mathrm{~m}, 1 \mathrm{H}), 7.05(\mathrm{~s}, 1 \mathrm{H}), 6.99-6.85(\mathrm{~m}, 4 \mathrm{H}), 6.71(\mathrm{~d}, J=15.4 \mathrm{~Hz}, 1 \mathrm{H})$, 5.98 (br s, 2H), 3.97 (s, 3H), $3.92(\mathrm{~s}, 3 \mathrm{H}), 3.64(\mathrm{~s}, 2 \mathrm{H}), 3.58(\mathrm{~s}, 2 \mathrm{H}), 2.52(\mathrm{~s}, 3 \mathrm{H}) \mathrm{ppm} ;{ }^{13} \mathrm{C}$ NMR (100 MHz, $\left.\mathrm{CDCl}_{3}+\mathrm{CD}_{3} \mathrm{OD}\right): \delta=182.49,176.35,148.87,147.49,147.10,147.09,143.08$, $133.92,127.40,127.29,127.09,123.72,123.02,116.24,115.26,114.96,113.50,110.74,105.72$, 77.06, 55.76, 55.68, 54.97, 52.94, 44.98 ppm; FTIR (ATR, v): 2959, 1767, 1693, 1570, 1513, 1446, $1412,1278 \mathrm{~cm}^{-1}$; HRMS (ESI): calcd. for: $\mathrm{C}_{24} \mathrm{H}_{26} \mathrm{NO}_{6}[\mathrm{M}+\mathrm{H}]^{+} 424.1755$; found 424.17516 .

(3E,5E)-3,5-Bis(4-hydroksy-3-metoksyfenylo)-1-metylopiperyd-4-on (9)

To $N$-metylopiperyd-4-one $(1.357 \mathrm{~g}, 12.02 \mathrm{mmol})$, vanillin $(4.226 \mathrm{~g}, 27.78 \mathrm{mmol})$ and acetic acid $(99 \%, 4 \mathrm{~mL})$ were added. The reaction was heated to $45^{\circ} \mathrm{C}$ for two days then the temperature was increased to $100{ }^{\circ} \mathrm{C}$ and heated for an additional day. After cooling to room temperature, $2 \mathrm{~mL}$ of concentrated hydrochloric acid was added, and the solution was evaporated to dryness under vacuum. To the obtained residue, water and $\mathrm{NaHCO}_{3}$ at a neutral $\mathrm{pH}$ were added and extracted with DCM $(4 \times 50 \mathrm{~mL})$. Combined organic extracts were dried over $\mathrm{Na}_{2} \mathrm{SO}_{4}$, filtered, and concentrated under a vacuum. The product was predicated by flash column chromatography (MeOH:DCM; 5:95) to yield a brown solid $(1.27 \mathrm{~g}, 22 \%)$.

Mp: 217-218 ${ }^{\circ} \mathrm{C}$ (lit. 195-197; Youssef, 2004); ${ }^{1} \mathrm{H}$ NMR (400 MHz, DMSO): $\delta=9.61$ (s, $\mathrm{H}), 7.53(\mathrm{~s}, 2 \mathrm{H}), 7.07$ (s, 2H), 6.99-6.85 (m, 4H), 3.82 (s, 6H), 3.71 (br s, 4H), 2.40 (s, 3H) ppm. NMR data were in agreement with those reported in literature [26].

\subsection{The Nitro Blue Tetrazolium (NBT) Test}

Superoxide anions have been generated in the solution by dissolving $6.5 \mathrm{mg}$ of $\mathrm{KO}_{2}$ powder and $90 \mathrm{mg}$ 18-crown-6-ether in DMSO $(50 \mathrm{~mL})$. The solution of NBT has been prepared by dissolving $10 \mathrm{mg}$ of NBT in $10 \mathrm{~mL}$ of DMSO. The control sample contained $1.5 \mathrm{~mL}$ of superoxide anions solution (DMSO), $0.5 \mathrm{~mL}$ of DMSO, and $0.1 \mathrm{~mL}$ of nitro blue tetrazolium solution. The solutions of curcumin and its analogues have been prepared in DMSO. The cuvette with the tested sample contained $1.5 \mathrm{~mL}$ of the superoxide anions solution, $0.5 \mathrm{~mL}$ of the antioxidant solution (curcumin and its analogues), and $0.1 \mathrm{~mL}$ of the nitro blue tetrazolium solution. The changes in absorbance were monitored spectrophotometrically at $560 \mathrm{~nm}$. The starting concentrations of the antioxidant solutions in the measuring cuvettes were selected so that possible products formed by curcumin as well as its analogues and superoxide anion radicals did not interfere with the absorbance at $560 \mathrm{~nm}$. Each measurement was repeated 3 times. The value of the superoxide anion scavenging by the tested compounds was calculated using the appropriate formula:

$$
\text { Scavenging }=\left(\mathrm{A}_{0}-\mathrm{A} / \mathrm{A}_{0}\right) \times 100 \%
$$

where $\mathrm{A}_{0}$ denotes the absorbance of the control sample and $\mathrm{A}$ is the absorbance of the tested sample.

\subsection{Cell Lines and Culture}

The breast cancer MCF-7 and MDA-MB-231 cell lines and human keratinocyte HaCaT cell line were obtained from American Type Culture Collection (ATCC, Manassas, VA, USA). The cell lines were cultured in Dulbecco's Modified Eagle's Medium supplemented with 10\% fetal bovine serum (FBS) and 1\% penicillin/streptomycin. The cell culture was maintained at $37{ }^{\circ} \mathrm{C}$ in an atmosphere containing $5 \% \mathrm{CO}_{2}$.

\subsection{Cell Viability Assay}

A cell viability assay (MTT assay) was performed according to the general protocol. Briefly, the cells $\left(1.2 \times 10^{6}\right.$ cells $\left./ \mathrm{mL}\right)$ were treated with solvent (referred to as con- 
trol) or treated with solutions of curcumin or its derivatives at concentrations ranging 7.81-100 $\mu \mathrm{M}$. The solutions of compounds were prepared in a culture medium with $1 \%$ penicillin/streptomycin and without fatal bovine serum. After $24 \mathrm{~h}$, the solution of $0.5 \mathrm{mg} / \mathrm{mL}$ MTT (3-[4,5-dimethylthiazol-2-yl]-2,5-diphenyl-tetrazolium bromide) was added. When the purple precipitate was clearly visible under the microscope, $100 \mu \mathrm{L}$ of DMSO was added to each well. The absorbance at $540 \mathrm{~nm}$ was determined using a microplate reader (Biogenet, Jozefow, Poland) and DigiRead Communication Software (Asys Hitech $\mathrm{GmbH}$, Eugendorf, Austria). The data were expressed as the percentage of untreated cells (control).

\subsection{Flow Cytometry}

Flow cytometry was used to analyze the generation of intracellular ROS. Briefly, the MCF-7, MDA-MB-231, and HaCat cell lines were seeded into 6-well plates at a density of $10^{6}$ cells per plate. Overnight, cells were untreated (as control) or treated with curcumin, compound 5, and compound 6 in concentrations of 6.25 and $25 \mu \mathrm{M}$ for $24 \mathrm{~h}$. After the incubation time, cells were exposed to $2^{\prime}, 7^{\prime}$-dichlorofluorescein for $30 \mathrm{~min}$, and the next cells were collected. A flow cytometry test measured the oxidized form of $2^{\prime}, 7^{\prime}$ dichlorofluorescein (excitation wavelength: $480 \mathrm{~nm}$; emission wavelength: $525 \mathrm{~nm}$ ). The data were expressed as the percentage of untreated cells.

\subsection{Western Blot}

The level of PTP1B phosphatase was determined by the Western blot technique. Briefly, the MCF-7 and MDA-MB-231 cell lines were non-treated (control) or treated with curcumin, compound 5, and compound 6 in concentrations of $25 \mu \mathrm{M}$, for $24 \mathrm{~h}$, then the cells were harvested, centrifuged, and lysed. The protein concentration was determined using the Bradford reagent [56]. The proteins were separated on a $4-20 \%$ gradient of polyacrylamide gel by electrophoresis (Bio-Rad Laboratories, Hercules, CA, USA). The separated proteins were transferred to a methanol-activated PVDF membrane in the TBE buffer using a semi-dry transfer device (GE Healthcare, Chicago, IL, USA). Membranes were incubated with primary PTP1B antibodies (Cell Signaling, Danvers, MA, USA), and overnight, with horseradish peroxidase (HRP)-conjugated secondary antibodies. Visualization was performed using chemiluminescence enhanced with a chemiluminescence reagent according to the manufacturer's protocol. The signal was read using ImageQuant LAS 500 (GE Healthcare, Chicago, IL, USA). Protein levels were quantified using densitometry analysis by the ImageJ program [57]. The results were normalized to $\beta$-actin.

\subsection{Real-Time Microscopy}

To obtain real-time effects for the tested compounds against the MDA-MB-231 cell line, the CytoSMART ${ }^{\circledR}$ Lux3 FL (CytoSMART technologies B.V, Lonza, Basel, Switzerland) was used. MDA-MB-231 cells were seeded into a $\varnothing 10 \mathrm{~cm}$ plate. When the cell confluence was $60 \%$, cells were rinsed with phosphate-buffered saline, and $5 \mathrm{~mL}$ of the medium with $10 \mu \mathrm{L}$ of $0.01 \mathrm{mg} / \mathrm{mL}$ propidium iodide (PI) (to visualization late apoptotic/necrotic cells) and curcumin or compound 5 at the concentration of $25 \mu \mathrm{M}$ was added. The prepared sample was immediately placed on the CytoSMART ${ }^{\circledR}$ Lux3 FL in the $\mathrm{CO}_{2}$ incubator and the image from the microscope was observed. The experiment was carried out used brightfield, green fluorescence (excitation: $452 / 45 \mathrm{~nm}$; emission: $512 / 23 \mathrm{~nm}$ ), and red fluorescence (excitation: 561/14 nm; emission: 630/90 nm) in parallel, or brightfield and red fluorescence in parallel. The snapshot was automatically performed with an interval of $5 \mathrm{~min}$ for $24 \mathrm{~h}$ in the $\mathrm{CO}_{2}$ incubator and collected on the cloud.cytosmart.com.

\subsection{Recombinant PTP1B Assay}

The analysis was performed in 96-well plates. Briefly, the final concentration of PTP1B phosphatase in reaction samples was $0.8 \mu \mathrm{g} / \mathrm{mL}(10 \mathrm{nM})$. The enzyme was treated with solvent (referred as control) or treated with the solution of curcumin and its derivatives 
in a concentration of $100 \mu \mathrm{M}$. The enzymatic activities of PTP1B phosphatase were measured using $1 \mathrm{mM}$ chromogenic substrate para-nitrophenyl phosphate $(p N P P)$ in $10 \mathrm{mM}$ HEPES buffer $\mathrm{pH} 7.4$, at $37^{\circ} \mathrm{C}$. The increase in absorbance (due to para-nitrophenol formation) is linearly proportional to the enzymatic activity concentration (with excessive substrate, i.e., zero-order kinetics) and was assessed at $405 \mathrm{~nm}$ on the microplate reader Jupiter (Biogenet, Jozefow, Poland) using DigiRead Communication Software (Asys Hitech $\mathrm{GmbH}$, Eugendorf, Austria). The data were expressed as the percentage of the untreated enzyme (control).

\subsection{Molecular Docking}

Protein tyrosine phosphatase 1B (PTP1B) crystal structure 1T48 (rcsb.org/structure/1T48) was selected for docking simulations. Molecular modelling studies were performed using Small-Molecule Drug Discovery Suite (Schrödinger LLC, New York, NY). Compound 6, BB3, and curcumin structures were optimized using the LigPrep tool, generating the most possible protonation states in the $\mathrm{pH}$ range of $7 \pm 0.2$ [58]. The proper protonation states were additionally verified using MarvinSketch software (Marvin version 19.4.0, ChemAxon, chemaxon.com). Crystal structure 1T48 was refined using Protein Preparation Wizard [59]: Hydrogen atoms were added, and the energy of the whole system was minimized using an OPLS3e force field [60]. Induced-fit docking (IFD) was used to dock compound $\mathbf{6}$ and determine its putative binding mode within PTP1B [61]. The grid box centroid was set automatically after selecting all the amino acids located up to $6 \AA$ from BB3 in its initial, crystallized position. No constraints were applied during IFD. As an output, the PTP1B-compound $\mathbf{6}$ complex was obtained and analyzed, based on the observed molecular interactions. Then, redocking of BB3 was performed (Glide software, Standard Precision mode) to validate the obtained model $[62,63]$. RMSD between originally co-crystalized and redocked ligands was calculated. Additional docking of curcumin, a known ligand of PTP1B, was done to compare its binding mode to the one obtained for compound 6.

\section{Conclusions}

In this research, we present the results of ten new curcumin derivatives featuring a 4-piperidone structure. Nine of these compounds have a 4-piperidone ring incorporated in a 1,3-diketone moiety. Compounds 1-3 contain fragments of the curcumin skeleton. Comparing the compounds containing the full curcumin skeleton or only selected elements of it allowed us to determine the fragments of the structure that are crucial for biological activity.

We observed that two compounds, 5 and $\mathbf{6}$, exhibited higher cytotoxic potential against breast cancer cell lines than curcumin. The main mechanism of action for these compounds could be the generation of intracellular ROS levels. Moreover, we have observed that a higher level of ROS resulted in the lower level of PTP1B in MCF-7 and MDA-MB-231 cell lines. It is worth noting that compound $\mathbf{6}$ showed the highest cytotoxic effect, also in low concentrations. Based on computational analysis, we suggest that this effect may be caused by allosteric inhibition of PTP1B.

According to the obtained results, it is important to look for new inhibitors that, by regulating protein tyrosine phosphatases, could have positive effects in preventing as well as treating cancer or autoimmune diseases. The search for novel compounds with a cytotoxic effect against breast cancer cells correlated with the inhibition of PTP1B protein tyrosine phosphatase may contribute to innovative targeted treatment.

Supplementary Materials: The following are available online at https:/ / www.mdpi.com/article / $10.3390 /$ ijms221910368/s1.

Author Contributions: Conceptualization, A.K.-J., T.K. and K.W.; methodology, A.K.-J., T.K., K.W., M.J., D.J., M.K. and R.Ł.; software, M.J. and M.K.; validation, A.K.-J., D.J., R.Ł., M.K. and M.G.P.; formal analysis, T.K. and A.K.-J.; investigation, T.K., K.W., M.J., J.D. and J.S.; synthesis and general analysis of compounds, K.W. and J.S.; cell culture, cell viability, recombinant PTP1B assay, 
flow cytometry, Western blot, real-time microscopy, and statistical analysis, T.K.; antioxidant effect analysis, J.D.; computational analysis: M.J.; resources, T.K., R.Ł. and M.G.-P.; data curation, T.K., K.W. and A.K.-J.; writing—original draft preparation, T.K., K.W., M.J., J.D. and A.K.-J.; writing-review and editing, A.K.-J., R.Ł., T.K., K.W., M.J., J.D., J.D., M.G.-P. and M.K.; visualization, T.K. and M.J.; supervision, A.K.-J.; project administration, T.K. and A.K.-J.; funding acquisition, T.K., R.Ł. and M.G.-P. All authors have read and agreed to the published version of the manuscript.

Funding: The studies concerning the antioxidant and anticancer role of curcumin and its derivatives were supported by the project POWR.03.05.00-00-z082/18 co-financed by the European Union through the European Social Fund under the Operational Programme Knowledge Education Development 2014-2020. KW, JS, and RL give thanks to the National Science Centre, Poland, grant number: 2014/15/B/ST5/04695 for the financial support for the synthesis part of this research.

Institutional Review Board Statement: All experiments were performed at least three times and the significance of the results was assessed with the appropriate tests. Statistical analysis was performed using ANOVA combined with the Dunnett test or T-test combined with the Wilcoxon test. The data were expressed as means \pm SD. Statistical analysis was performed using GraphPad Prism software.

Data Availability Statement: Data is contained within the article or supplementary material.

Acknowledgments: M.G.-P. acknowledges support from ST46 funding (Medical University of Gdansk, Poland). T.K. acknowledges CytoSMART technologies B.V. for the possibility of using a LUX-3 FL microscopy for carrying out our studies.

Conflicts of Interest: The authors declare no conflict of interest. The funders had no role in the design of the study; in the collection, analyses, or interpretation of data; in the writing of the manuscript, or in the decision to publish the results.

\section{References}

1. Priyadarsini, K.; Gandhi, W.; Kunwar, A. Important chemical structural features of curcumin and its derivatives: How do they influence their anticancer activity? Indian J. Biochem. Biophys. 2020, 57, 228-235.

2. Hossain, M.; Das, U.; Dimmock, J. Recent advances in $\alpha, \beta$-unsaturated carbonyl compounds as mitochondrial toxins. Eur. J. Med. Chem. 2019, 183, 111687. [CrossRef] [PubMed]

3. Lao, C.D.; Ruffin, M.T., IV; Normolle, D.; Heath, D.D.; Murray, S.I.; Bailey, J.M.; Boggs, M.E.; Crowell, J.; Rock, C.L.; Brenner, D.E. Dose escalation of a curcuminoid formulation. BMC Complement. Altern. Med. 2006, 6, 10. [CrossRef] [PubMed]

4. Ak, T.; Gülçin, I. Antioxidant and radical scavenging properties of curcumin. Chem. Biol. Interact. 2008, 174, 27-37. [CrossRef]

5. Sandur, S.K.; Pandey, M.K.; Sung, B.; Ahn, K.S.; Murakami, A.; Sethi, G.; Limtrakul, P.; Badmaev, V.; Aggarwal, B.B. Curcumin, demethoxycurcumin, bisdemethoxycurcumin, tetrahydrocurcumin and turmerones differentially regulate anti-inflammatory and anti-proliferative responses through a ROS-independent mechanism. Carcinogenesis. 2007, 28, 1765-1773. [CrossRef] [PubMed]

6. Sarwar, S.; Netzel, G.; Netzel, M.E.; Mereddy, R.; Phan, A.D.T.; Hong, H.T.; Cozzolino, D.; Sultanbawa, Y. Impact of CurcuminMediated Photosensitization on Fungal Growth, Physicochemical Properties and Nutritional Composition in Australian Grown Strawberry. Food Anal. Methods. 2020, 14, 465-472. [CrossRef]

7. Tomeh, M.A.; Hadianamrei, R.; Zhao, X. A Review of Curcumin and Its Derivatives as Anticancer Agents. Int. J. Mol. Sci. 2019, 20, 1033. [CrossRef] [PubMed]

8. Bairwa, K.; Grover, J.; Kania, M.; Jachak, S.M. Recent developments in chemistry and biology of curcumin analogues. RSC Adv. 2014, 4, 13946-13978. [CrossRef]

9. Raduly, F.M.; Raditoiu, V.; Raditoiu, A.; Purcar, V. Curcumin: Modern Applications for a Versatile Additive. Coatings. 2021, 11, 519. [CrossRef]

10. Wang, Y.J.; Pan, M.H.; Cheng, A.L.; Lin, L.I.; Ho, Y.S.; Hsieh, C.Y.; Lin, J.K. Stability of curcumin in buffer solutions and characterization of its degradation products. J. Pharm. Biomed. Anal. 1997, 15, 1867-1876. [CrossRef]

11. Esatbeyoglu, T.; Huebbe, P.; Ernst, I.M.A.; Chin, D.; Wagner, A.E.; Rimbach, G. Curcumin—From Molecule to Biological Function. Angew. Chem. Int. Ed. 2012, 51, 5308-5332. [CrossRef]

12. Hewlings, S.J.; Kalman, D.S. Curcumin: A Review of Its Effects on Human Health. Foods 2017, 6, 92. [CrossRef]

13. Sanidad, K.Z.; Sukamtoh, E.; Xiao, H.; McClements, D.J.; Zhang, G. Curcumin: Recent Advances in the Development of Strategies to Improve Oral Bioavailability. Annu Rev. Food Sci Technol. 2019, 10, 597-617. [CrossRef] [PubMed]

14. Huber, I.; Zupkó, I.; Kovács, I.J.; Minorics, R.; Gulyás-Fekete, G.; Maász, G.; Perjési, P. Synthesis and antiproliferative activity of cyclic arylidene ketones: A direct comparison of monobenzylidene and dibenzylidene derivatives. Monatshefte Chemie-Chem. Mon. 2015, 146, 973-981. [CrossRef]

15. Hossain, M.; Das, S.; Das, U.; Doroudi, A.; Zhu, J.; Dimmock, J.R. Novel hybrid molecules of 3,5-bis(benzylidene)-4-piperidones and dichloroacetic acid which demonstrate potent tumour-selective cytotoxicity. Bioorg. Med. Chem. Lett. 2020, $30,126878$. [CrossRef] 
16. Pati, H.N.; Das, U.; Das, S.; Bandy, B.; De Clercq, E.; Balzarini, J.; Kawase, M.; Sakagami, H.; Quail, J.W.; Stables, J.P.; et al. The cytotoxic properties and preferential toxicity to tumour cells displayed by some 2,4-bis(benzylidene)-8-methyl-8-azabicyclo [3.2.1] octan-3-ones and 3,5-bis(benzylidene)-1-methyl-4-piperidones. Eur. J. Med. Chem. 2009, 44, 54-62. [CrossRef]

17. Nagaraju, G.P.; Benton, L.; Bethi, S.R.; Shoji, M.; El-Rayes, B.F. Curcumin analogs: Their roles in pancreatic cancer growth and metastasis. Int. J. Cancer 2019, 145, 10-19. [CrossRef]

18. Moreira, J.; Saraiva, L.; Pinto, M.M.; Cidade, H. Diarylpentanoids with antitumor activity: A critical review of structure-activity relationship studies. Eur. J. Med. Chem. 2020, 192, 112177. [CrossRef]

19. Lin, L.; Shi, Q.; Su, C.Y.; Shih, C.C.Y.; Lee, K.H. Antitumor agents 247. New 4-ethoxycarbonylethyl curcumin analogs as potential antiandrogenic agents. Bioorg. Med. Chem. 2006, 14, 2527-2534. [CrossRef] [PubMed]

20. Alonso, A.; Sasin, J.; Bottini, N.; Friedberg, I.; Friedberg, I.; Osterman, A.; Godzik, A.; Hunter, T.; Dixon, J.; Mustelin, T. Protein tyrosine phosphatases in the human genome. Cell 2004, 117, 699-711. [CrossRef]

21. Den Hertog, J.; Groen, A.; Van Der Wijk, T. Redox regulation of protein-tyrosine phosphatases. Arch. Biochem. Biophys. 2005, 434, 11-15. [CrossRef]

22. Hendriks, W.J.A.J.; Elson, A.; Harroch, S.; Stoker, A.W. Protein tyrosine phosphatases: Functional inferences from mouse models and human diseases. FEBS J. 2008, 275, 816-830. [CrossRef] [PubMed]

23. Ostman, A.; Hellberg, C.; Böhmer, F.D. Protein-tyrosine phosphatases and cancer. Nat. Rev. Cancer 2006, 6, 307-320. [CrossRef] [PubMed]

24. Aceto, N.; Bentires-Alj, M. Targeting protein-tyrosine phosphatases in breast cancer. Oncotarget 2012, 3, 514-515. [CrossRef] [PubMed]

25. Wolosewicz, K.; Podgorska, K.; Rutkowska, E.; Lazny, R. Synthesis of Dicarbonyl Curcumin Analogues Containing the Tropane Scaffold. Eur. J. Org. Chem. 2019, 2019, 4662-4674. [CrossRef]

26. Youssef, K.M.; El-Sherbeny, M.A.; El-Shafie, F.S.; Farag, H.A.; Al-Deeb, O.A.; Awadalla, S.A.A. Synthesis of Curcumin Analogues as Potential Antioxidant, Cancer Chemopreventive Agents. Arch. Pharm. (Weinheim) 2004, 337, 42-54. [CrossRef]

27. George, H.; Roth, H.J. Photoisomerisierung und Cyclo-1,2-Addition $\alpha$, $\beta$-ungesättigter Cyclanone. Tetrahedron Lett. 1971, 12 , 4057-4060. [CrossRef]

28. Piotrowska-Kirschling, A.; Drzeżdżon, J.; Kloska, A.; Wyrzykowski, D.; Chmurzyński, L.; Jacewicz, D. Antioxidant and Cytoprotective Activity of Oxydiacetate Complexes of Cobalt(II) and Nickel(II) with 1,10-Phenantroline and 2,2'-Bipyridine. Biol. Trace Elem. Res. 2018, 185, 244-251. [CrossRef]

29. Abu, N.; Akhtar, M.N.; Ho, W.Y.; Yeap, S.K.; Alitheen, N.B. 3-bromo-1-hydroxy-9,10-anthraquinone (BHAQ) inhibits growth and migration of the human breast cancer cell lines MCF-7 and MDA-MB231. Molecules 2013, 18, 10367-10377. [CrossRef]

30. Pessina, A.; Raimondi, A.; Cerri, A.; Piccirillo, M.; Neri, M.G.; Croera, C.; Foti, P.; Berti, E. High sensitivity of human epidermal keratinocytes (HaCaT) to topoisomerase inhibitors. Cell Prolif. 2001, 34, 243-252. [CrossRef]

31. Badmus, J.A.; Oyemomi, S.A.; Adedosu, O.T.; Yekeen, T.A.; Azeez, M.A.; Adebayo, E.A.; Lateef, A.; Badeggi, U.M.; Botha, S.; Hussein, A.A.; et al. Photo-assisted bio-fabrication of silver nanoparticles using Annona muricata leaf extract: Exploring the antioxidant, anti-diabetic, antimicrobial, and cytotoxic activities. Heliyon 2020, 6, E05413. [CrossRef]

32. Polat, E.; Kang, K. Natural Photosensitizers in Antimicrobial Photodynamic Therapy. Biomedicines 2021, 9, 584. [CrossRef] [PubMed]

33. Ghorbani, J.; Rahban, D.; Aghamiri, S.; Teymouri, A.; Bahador, A. Photosensitizers in antibacterial photodynamic therapy: An overview. Laser Ther. 2018, 27, 293. [CrossRef] [PubMed]

34. Damyeh, M.S.; Mereddy, R.; Netzel, M.E.; Sultanbawa, Y. An insight into curcumin-based photosensitization as a promising and green food preservation technology. Compr. Rev. Food Sci. Food Saf. 2020, 19, 1727-1759. [CrossRef]

35. Kostrzewa, T.; Przychodzen, P.; Gorska-Ponikowska, M.; Kuban-Jankowska, A. Curcumin and Cinnamaldehyde as PTP1B Inhibitors with Antidiabetic and Anticancer Potential. Anticancer Res. 2019, 39, 745-749. [CrossRef] [PubMed]

36. Tonks, N.K.; Muthuswamy, S.K. A Brake Becomes an Accelerator: PTP1B-A New Therapeutic Target for Breast Cancer. Cancer Cell 2007, 11, 214-216. [CrossRef]

37. Barr, A.J. Protein tyrosine phosphatases as drug targets: Strategies and challenges of inhibitor development. Future Med. Chem. 2010, 2, 1563-1576. [CrossRef] [PubMed]

38. Julien, S.G.; Dubé, N.; Read, M.; Penney, J.; Paquet, M.; Han, Y.; Kennedy, B.P.; Muller, W.J.; Tremblay, M.L. Protein tyrosine phosphatase 1B deficiency or inhibition delays ErbB2-induced mammary tumorigenesis and protects from lung metastasis. Nat. Genet. 2007, 39, 338-346. [CrossRef]

39. Liao, S.; Li, J.; Yu, L.; Sun, S. Protein tyrosine phosphatase 1B expression contributes to the development of breast cancer. J. Zhejiang Univ. Sci. B 2017, 18, 334. [CrossRef]

40. Liu, X.; Chen, Q.; Hu, X.-G.; Zhang, X.-C.; Fu, T.-W.; Liu, Q.; Liang, Y.; Zhao, X.-L.; Zhang, X.; Ping, Y.-F.; et al. PTP1B promotes aggressiveness of breast cancer cells by regulating PTEN but not EMT. Tumour Biol. 2016, 37, 13479-13487. [CrossRef]

41. Tonks, N.K. Protein tyrosine phosphatases: From genes, to function, to disease. Nat. Rev. Mol. Cell Biol. 2006, 7, 833-846. [CrossRef] [PubMed]

42. Parsons, S.J.; Parsons, J.T. Src family kinases, key regulators of signal transduction. Oncogene 2004, 23, 7906-7909. [CrossRef] [PubMed] 
43. Summy, J.; Gallick, G. Src family kinases in tumor progression and metastasis. Cancer Metastasis Rev. 2003, 22, 337-358. [CrossRef] [PubMed]

44. Biscardi, J.S.; Ishizawar, R.C.; Silva, C.M.; Parsons, S.J. Tyrosine kinase signalling in breast cancer: Epidermal growth factor receptor and c-Src interactions in breast cancer. Breast Cancer Res. 2000, 2, 203. [CrossRef] [PubMed]

45. Lai, Y.-H.; Chen, M.-H.; Lin, S.-Y.; Lin, S.-Y.; Wong, Y.-H.; Yu, S.-L.; Chen, H.-W.; Yang, C.-H.; Chang, G.-C.; Chen, J.J.W. Rhodomycin A, a novel Src-targeted compound, can suppress lung cancer cell progression via modulating Src-related pathways. Oncotarget 2015, 6, 26252-26265. [CrossRef] [PubMed]

46. Bjorge, J.; Jakymiw, A.; Fujita, D. Selected glimpses into the activation and function of Src kinase. Oncogene 2000, 19, 5620-5635. [CrossRef] [PubMed]

47. Chen, K.; Lu, P.; Beeraka, N.; Sukocheva, O.; Madhunapantula, S.; Liu, J.; Sinelnikov, M.; Nikolenko, V.; Bulygin, K.; Mikhaleva, L.; et al. Mitochondrial mutations and mitoepigenetics: Focus on regulation of oxidative stress-induced responses in breast cancers. Semin. Cancer Biol. 2020. [CrossRef]

48. Meng, T.; Buckley, D.; Galic, S.; Tiganis, T. Regulation of insulin signaling through reversible oxidation of the protein-tyrosine phosphatases TC45 and PTP1B. J. Biol. 2004, 279, 37716-37725. [CrossRef]

49. Jones, D. Radical-free biology of oxidative stress. Am. J. Physiol. Physiol. 2008, 295, C849-C868. [CrossRef]

50. Caselli, A.; Marzocchini, R.; Camici, G.; Manao, G. The inactivation mechanism of low molecular weight phosphotyrosine-protein phosphatase by $\mathrm{H}_{2} \mathrm{O}_{2}$. J. Biol. 1998, 273, 32554-32560. [CrossRef]

51. Karisch, R.; Fernandez, M.; Taylor, P.; Virtanen, C.; St-Germain, J.R.; Jin, L.L.; Harris, I.S.; Mori, J.; Mak, T.W.; Senis, Y.A.; et al. Global proteomic assessment of the classical protein-tyrosine phosphatome and "Redoxome". Cell 2011, 146, 826-840. [CrossRef] [PubMed]

52. Ireson, C.; Orr, S.; Jones, D.J.; Verschoyle, R.; Lim, C.K.; Luo, J.L.; Howells, L.; Plummer, S.; Jukes, R.; Williams, M.; et al. Characterization of metabolites of the chemopreventive agent curcumin in human and rat hepatocytes and in the rat in vivo, and evaluation of their ability to inhibit phorbol ester-induced prostaglandin E2 production. Cancer Res. 2001, 61, 1058-1064. [PubMed]

53. Nelson, K.M.; Dahlin, J.L.; Bisson, J.; Graham, J.; Pauli, G.F.; Walters, M.A. The Essential MedicinalChemistry of Curcumin: Miniperspective. J. Med. Chem. 2017, 60, 1620. [CrossRef] [PubMed]

54. Dikusar, E.A.; Kozlov, N.G. Methyl-and ethyl carbonates derived from vanillin and vanillal in the synthesis of nitrogen-containing compounds. Russ. J. Gen. Chem. 2007, 77, 905-910. [CrossRef]

55. Gu, X.; Wang, X.; Wang, F.; Sun, H.; Liu, J.; Xie, Y.; Xiang, M. Pyrrolidine-Mediated Direct Preparation of (E)-Monoarylidene Derivatives of Homo- and Heterocyclic Ketones with Various Aldehydes. Molecules 2014, 19, 1976-1989. [CrossRef] [PubMed]

56. Bradford, M.M. A rapid and sensitive method for the quantitation of microgram quantities of protein utilizing the principle of protein-dye binding. Anal. Biochem. 1976, 72, 248-254. [CrossRef]

57. ImageJ; version 1.8.0_172; Software for Image Processing and Analysis in Java; U. S. National Institutes of Health: Bethesda, MD, USA, 2018.

58. Schrödinger Release 2018-4: LigPrep; Schrödinger, LLC: New York, NY, USA, 2018.

59. Schrödinger Release 2018-4: Protein Preparation Wizard; Epik, Schrödinger, LLC: New York, NY, USA; Impact, Schrödinger, LLC: New York, NY, USA; Prime, Schrödinger, LLC: New York, NY, USA, 2018.

60. Madhavi Sastry, G.; Adzhigirey, M.; Day, T.; Annabhimoju, R.; Sherman, W. Protein and ligand preparation: Parameters, protocols, and influence on virtual screening enrichments. J. Comput. Mol. Des. 2013, 27, 221-234. [CrossRef] [PubMed]

61. Sherman, W.; Day, T.; Jacobson, M.P.; Friesner, R.A.; Ramy, F. Novel Procedure for Modeling Ligand/Receptor Induced Fit Effects. J. Med. Chem. 2005, 49, 534-553. [CrossRef]

62. Halgren, T.A.; Murphy, R.B.; Friesner, R.A.; Beard, H.S.; Frye, L.L.; Pollard, W.T.; Banks, J.L. Glide: A New Approach for Rapid, Accurate Docking and Scoring. 2. Enrichment Factors in Database Screening. J. Med. Chem. 2004, 47, 1750-1759. [CrossRef]

63. Schrödinger Release 2018-4: Glide; Schrödinger, LLC: New York, NY, USA, 2018. 